\title{
The Economic Benefits of Multipurpose Reservoirs in the United States-Federal Hydropower Fleet
}

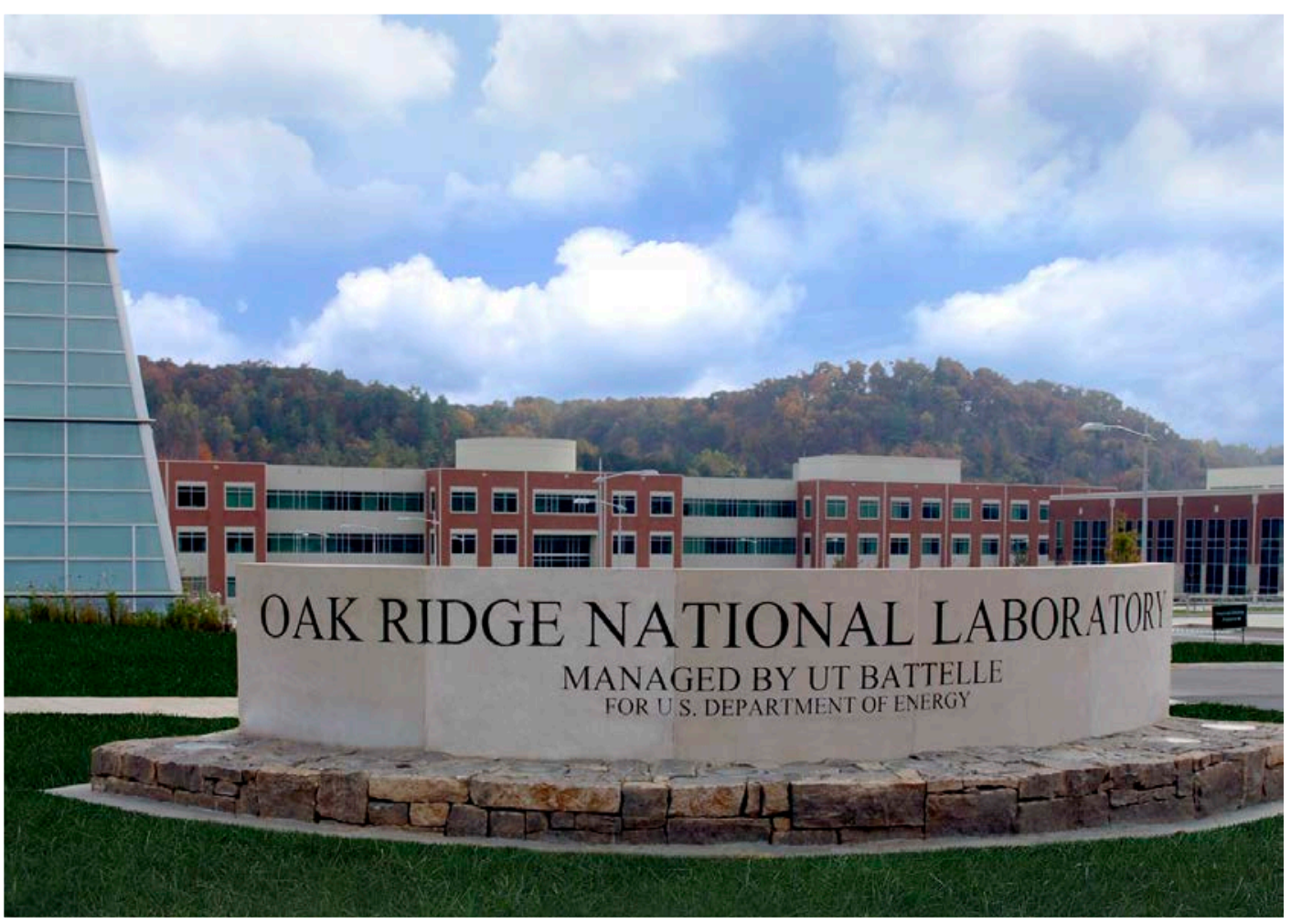

Approved for public release. Distribution is unlimited.
Marisol Bonnet

Adam Witt

Kevin Stewart

Boualem Hadjerioua

Miles Mobley

September 2015 


\section{DOCUMENT AVAILABILITY}

Reports produced after January 1, 1996, are generally available free via US Department of Energy (DOE) SciTech Connect.

Website http://www.osti.gov/scitech/

Reports produced before January 1, 1996, may be purchased by members of the public from the following source:

National Technical Information Service

5285 Port Royal Road

Springfield, VA 22161

Telephone 703-605-6000 (1-800-553-6847)

TDD 703-487-4639

Fax 703-605-6900

E-mail info@ntis.gov

Website http://www.ntis.gov/help/ordermethods.aspx

Reports are available to DOE employees, DOE contractors, Energy Technology Data Exchange representatives, and International Nuclear Information System representatives from the following source:

Office of Scientific and Technical Information

PO Box 62

Oak Ridge, TN 37831

Telephone 865-576-8401

Fax 865-576-5728

E-mail reports@osti.gov

Website http://www.osti.gov/contact.html

This report was prepared as an account of work sponsored by an agency of the United States Government. Neither the United States Government nor any agency thereof, nor any of their employees, makes any warranty, express or implied, or assumes any legal liability or responsibility for the accuracy, completeness, or usefulness of any information, apparatus, product, or process disclosed, or represents that its use would not infringe privately owned rights. Reference herein to any specific commercial product, process, or service by trade name, trademark, manufacturer, or otherwise, does not necessarily constitute or imply its endorsement, recommendation, or favoring by the United States Government or any agency thereof. The views and opinions of authors expressed herein do not necessarily state or reflect those of the United States Government or any agency thereof. 


\title{
Environmental Sciences Division
}

\section{THE ECONOMIC BENEFITS OF MULTIPURPOSE RESERVOIRS IN THE UNITED STATES- FEDERAL HYDROPOWER FLEET}

\author{
Marisol Bonnet \\ Adam Witt \\ Kevin Stewart \\ Boualem Hadjerioua \\ Miles Mobley
}

Date Published: September 2015

\author{
Prepared for \\ U.S. Department of Energy \\ Wind and Water Program \\ Prepared by \\ OAK RIDGE NATIONAL LABORATORY \\ Oak Ridge, Tennessee 37831-6283 \\ Managed by \\ UT-BATTELLE, LLC \\ for the \\ US DEPARTMENT OF ENERGY \\ under contract DE-AC05-00OR22725
}




\section{TABLE OF CONTENTS}

\section{Page}

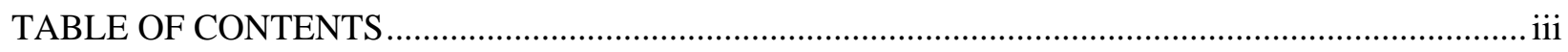

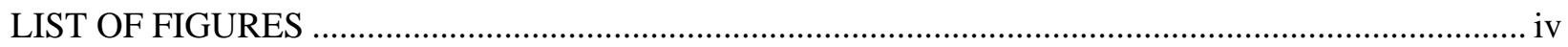

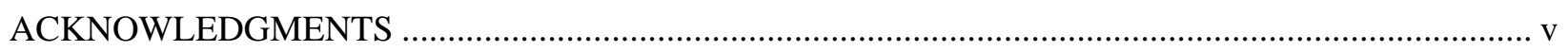

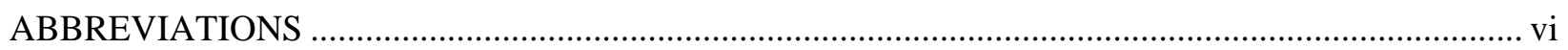

ABSTRACT.

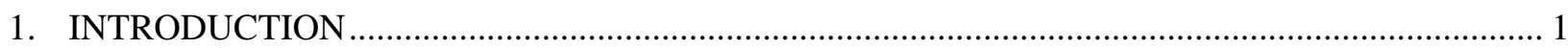

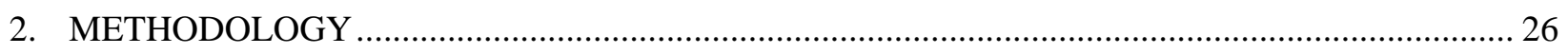

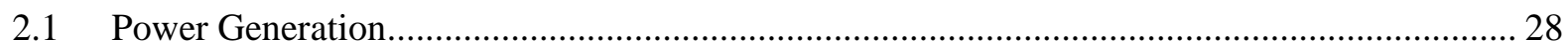

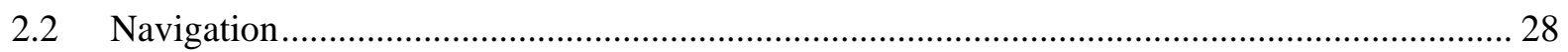

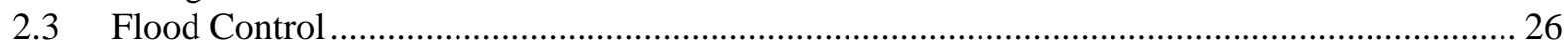

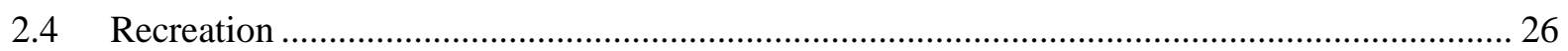

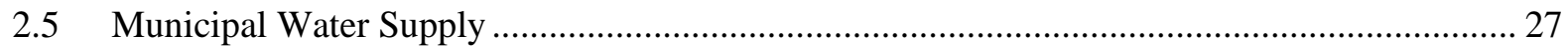

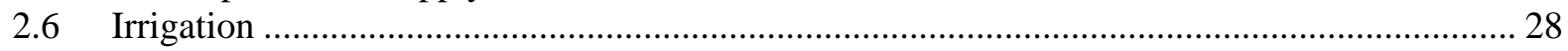

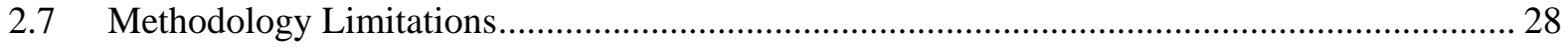

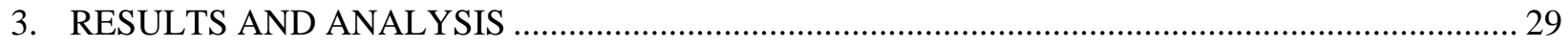

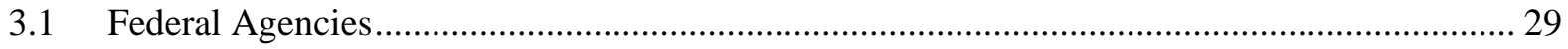

3.2 USACE: All Civil Works vs. Hydropower Projects …............................................................. 34

3.3 Cumberland River System Case Study …............................................................................... 35

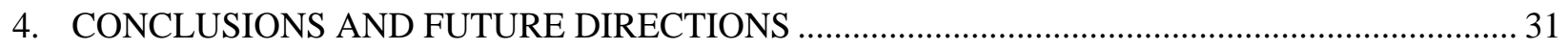

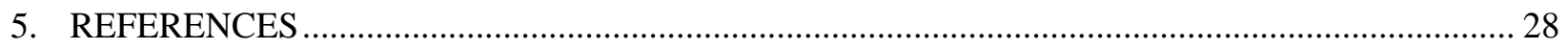




\section{LIST OF FIGURES}

Figure

Page

Figure 1 - Distribution of authorized uses for all federal multipurpose hydropower reservoirs. The percentage of multipurpose hydropower reservoirs that are authorized for each respective additional purpose is shown in a circle at the end of each bar (left).

Source: NHAAP (2015). 2

Figure 2 - Frequency distribution of authorized uses based on installed hydropower capacity. ................. 2

Figure 3 - Map of all powered and non-powered navigation locks in the United States........................... 26

Figure 4 - Distribution of economic benefit per use per agency.............................................................. 29

Figure 5 - Average percentage of power benefit per reservoir. Columns depict the number of quantifiable purposes, while rows represent a range of installed capacity....

Figure 6 - Breakdown of economic benefits by installed capacity.

Figure 7 - Weighting of hydropower benefit versus an alternate multipurpose benefit. In each case, the solid black line indicates an even split between benefits. Any points below the line indicate the hydropower benefit is greater, while points above the line indicate the respective benefit is greater than the hydropower benefit. Points are colored by mode of operation (NHAAP, 2015) and sized by installed capacity.

Figure 8 - Distribution of the economic benefits of multipurpose reservoirs in Western versus Eastern U.S.

Figure 9 - Annual USACE hydropower economic benefit compared to the 2010 annual economic benefit of all USACE Civil Works programs.

Figure 10 - NED benefits distribution of the Cumberland River System multipurpose projects. Spatial distribution of reservoirs is not to scale.

Figure 11 - Top USACE recreation projects by annual visitor. Cumberland system reservoirs are shown in red.

Figure 12 - Spatial distribution of reservoirs in relation to Nashville compared with annual recreation visitors.

Figure 13 - Relationship between reservoir surface area and recreation benefit as a percentage of total benefit. Marker areas are scaled according to installed capacity.

Figure 14 - Spatial distribution of navigation benefits in relation to Nashville (left). Count of vessels locked (right).

Figure 15 - Tonnage of commodity locked. Cordell Hull recorded 9600 tons of manufactured equipment and machinery locked, though the number is too small to display. The chart reflects reported tonnage and not reduced tonnage.

Figure 16 - Annual flood control benefit. Marker areas are scaled according to percentage of system storage capacity in the reservoir. Square markers indicate tributary reservoirs.

Figure 17 - Annual hydropower economic benefit. Marker areas are scaled according to installed capacity. 


\section{ACKNOWLEDGMENTS}

The authors would like to acknowledge and express their appreciation to all the following individuals and programs for their review, comments, and support of this report:

\section{Tennessee Valley Authority}

- James H. Everett

- Thomas Barnett

\section{U.S. Army Corps of Engineers}

- Bob Sneed

- Clint Neel

\section{U.S. Bureau of Reclamation}

- Merlynn Bender

- Kerry McCalman

- Yolanda Smith

- Michael Pulskamp

- Max Spiker

University of Tennessee's Center for Transportation Research

- Larry Bray

- Mark Burton

\section{Institute for Water Resources}

- Laura Vicinie

\section{Oak Ridge National Laboratory}

- Rocio Uria Martinez

- Nicole Samu 


\section{ABBREVIATIONS}

$\begin{array}{ll}\text { CVM } & \text { Contingent Valuation Method } \\ \text { DOI } & \text { Department of the Interior } \\ \text { EDF } & \text { Electricité de France } \\ \text { GIS } & \text { Geographic Information System } \\ \text { IWR } & \text { Institute for Water Resources } \\ \text { NEB } & \text { National Economic Benefit } \\ \text { NED } & \text { National Economic Development } \\ \text { NHAAP } & \text { National Hydropower Asset Assessment Program } \\ \text { PR\&G } & \text { Principles, Requirements, and Guidelines } \\ \text { PSH } & \text { Pumped Storage Hydropower } \\ \text { SS } & \text { Shipper Savings } \\ \text { TCM } & \text { Travel Cost Method } \\ \text { TVA } & \text { Tennessee Valley Authority } \\ \text { USACE } & \text { United States Army Corps of Engineers } \\ \text { USBR } & \text { Bureau of Reclamation } \\ \text { USDA } & \text { U.S. Department of Agriculture } \\ \text { WCSC } & \text { Waterborne Commerce Statistics Center } \\ \text { WWC } & \text { World Water Council }\end{array}$




\begin{abstract}
The United States is home to over 80,000 dams, of which approximately 3\% are equipped with hydroelectric generating capabilities. When a dam serves as a hydropower facility, it provides a variety of energy services that range from clean, reliable power generation to load balancing that supports grid stability. In most cases, the benefits of dams and their associated reservoirs go far beyond supporting the nation's energy demand. As evidenced by the substantial presence of non-powered dams with the ability to store water in large capacities, the primary purpose of a dam may not be hydropower, but rather one of many other purposes. A dam and reservoir may support navigation, recreation, flood control, irrigation, and water supply, with each multipurpose benefit providing significant social and economic impacts on a local, regional, and national level. When hydropower is one of the services provided by a multipurpose reservoir, it is then part of an integrated system of competing uses. Operating rules, management practices, consumer demands, and environmental constraints must all be balanced to meet the multipurpose project's objectives.
\end{abstract}

When federal dams are built, they are authorized by Congress to serve one or more functions. Legislation such as the Water Resources Development Act regulates the operation of the facility in order to coordinate the authorized uses and ensure the dam's intended objectives are being met. While multipurpose reservoirs account for billions of dollars in contributions to National Economic Development (NED) every year, no attempt has been made to evaluate their benefits on a national scale. This study is an on-going work conducted by Oak Ridge National Laboratory in an effort to estimate the economic benefits of multipurpose hydropower reservoirs in the United States. Given the important role that federal hydropower plays in the U.S., the first focus of this research will target the three main federal hydropower owners - Tennessee Valley Authority, U.S. Army Corps of Engineers, and U.S. Bureau of Reclamation. Together these three agencies own and operate 157 powered dams which account for almost half of the total installed hydropower capacity in the U.S. Future work will include engaging publiclyowned utilities and the private sector in order to quantify the benefits of all multipurpose hydropower reservoirs in the U.S. 


\section{INTRODUCTION}

The majority of U.S. federal reservoirs serve multiple purposes, including hydropower, navigation, flood control, recreation, irrigation, and municipal and industrial (M\&I) water supply. The federal government has been involved in managing reservoir systems since the 19th century, when the Rivers and Harbors Act of 1824 was introduced to improve the inland navigation system. In 1902 Congress passed the Reclamation Act, which funded irrigation projects in 20 states in the West and created the U.S. Bureau of Reclamation (USBR) to administer the program. The act led to rapid construction of dams on almost every major western river. Following a series of floods in every major river basin between 1890 and 1927, intensified concerns over flood damages led to the Flood Control Act of 1936, in which Congress deemed flood management a federal activity. The act appropriated funds for the primary purpose of flood control, and authorized the U.S. Army Corps of Engineers (USACE) to construct hundreds of flood control structures. The Flood Control Act of 1944 helped solidify the federal government's move towards a multipurpose approach: Section 4 authorized the construction, operation, and maintenance of recreation facilities at USACE water resources development projects; Section 5 granted the Secretary of the Interior the authority to sell power generated at federal projects; Section 6 authorized the USACE to provide surplus water at its facilities for M\&I use; and Section 8 allowed USACE reservoirs to be used for irrigation purposes (1944 FCA; P.L 78-534). The Water Resources Development Act, a biennial piece of legislation first introduced in 1974, is now the primary statute for federal water resources planning, governing existing water infrastructure and their multiple uses as well as the development of proposed projects.

Federal involvement in water management bolstered the development of hundreds of multipurpose projects throughout the U.S. that are to this day providing services for millions of people in both rural and urban areas. The USACE operates and maintains all federal navigation facilities. The USBR programs are crucial for irrigation and hydropower generation in the West. The Tennessee Valley Authority (TVA), established by Congress in 1933, provides the Southeast with hydropower, flood control, and recreation, among other uses. Together these three agencies own 157 powered dams and account for nearly half of total installed hydropower capacity in the U.S. Most of these dams and their associated reservoirs are authorized for more than one purpose in addition to hydropower generation (Figure 1, left). Each dam's congressionally-authorized purposes are documented in the National Hydropower Asset Assessment Program (NHAAP) database, along with other relevant dam characteristics used in this analysis (NHAAP, 2015). The majority of hydropower reservoirs are authorized for recreational use (119 out of 157, or 76\%) while only 42 are authorized for navigation. Over $58 \%$ of federal reservoirs help prevent flood damages; of that percentage, two thirds were built for the primary purpose of flood control. The distribution of reservoirs authorized for a given number of purposes reveals a dominant trend (Figure 1, right): over 80\% of all federal reservoirs serve three or more purposes. Since this study only considers reservoirs with hydroelectric generation as an authorized use, the $6.4 \%$ of reservoirs authorized for only one purpose are solely authorized for hydropower. The remaining portions of the graph represent a combination of hydropower and another purpose, such as flood control or irrigation. 

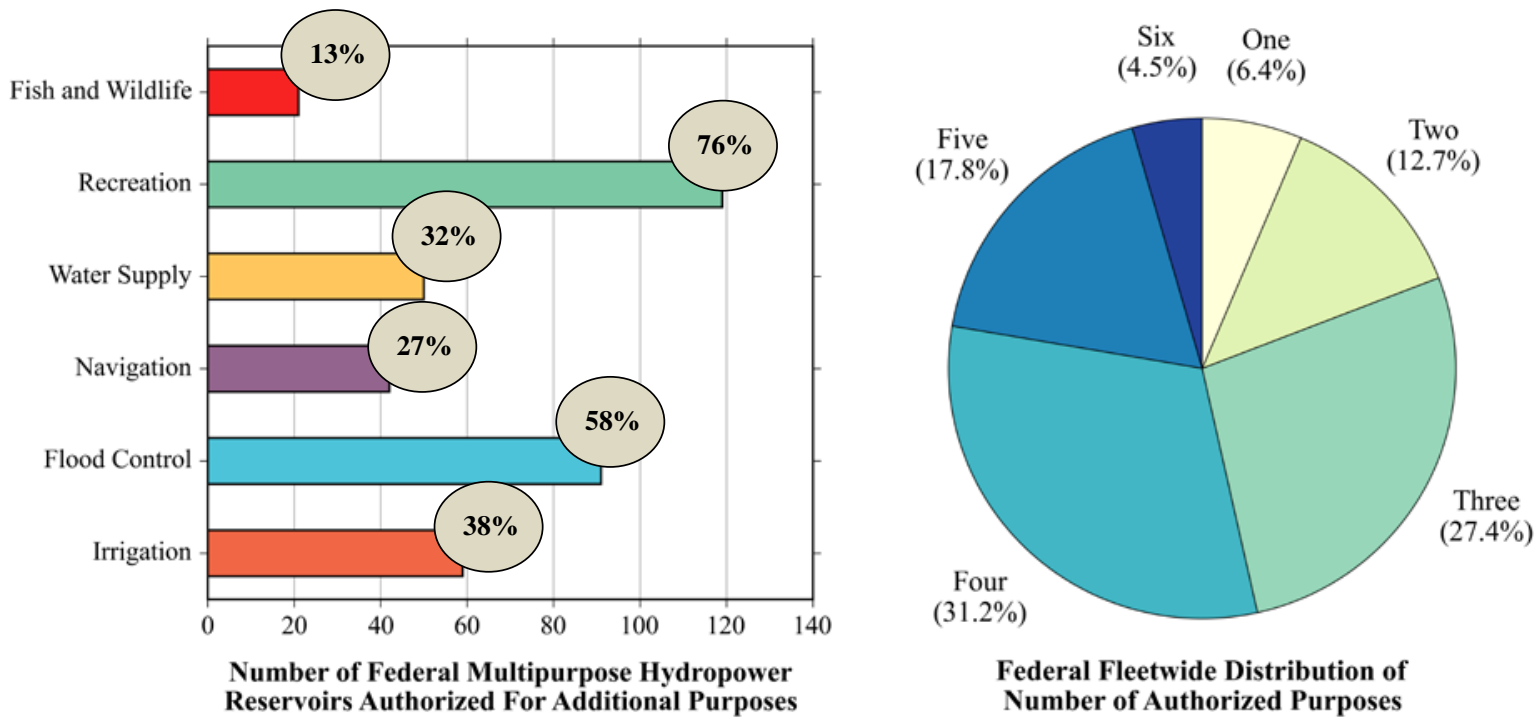

Figure 1 - Distribution of authorized uses for all federal multipurpose hydropower reservoirs. The percentage of multipurpose hydropower reservoirs that are authorized for each respective additional purpose is shown in a circle at the end of each bar (left). Source: NHAAP (2015).

Federal hydropower plants operating at multipurpose reservoirs range in installed capacity, from less than $1 \mathrm{MW}$ to over 6,000 MW. This wide range of generation potential is accompanied by similar variability in reservoir storage volume and surface area, which results in many beneficial opportunities for multipurpose use. The relationship between installed hydropower capacity and number of authorized purposes shows a general trend of greater number of purposes as installed capacity increases (Figure 2). The majority of plants with a capacity greater than $100 \mathrm{MW}$ are authorized for four purposes, while most plants with a capacity lower than 100 MW serve only three purposes. Reservoirs authorized for six uses are almost equally distributed between plants with less than $100 \mathrm{MW}, 100-500 \mathrm{MW}$, and greater than 500 MW installed capacity.

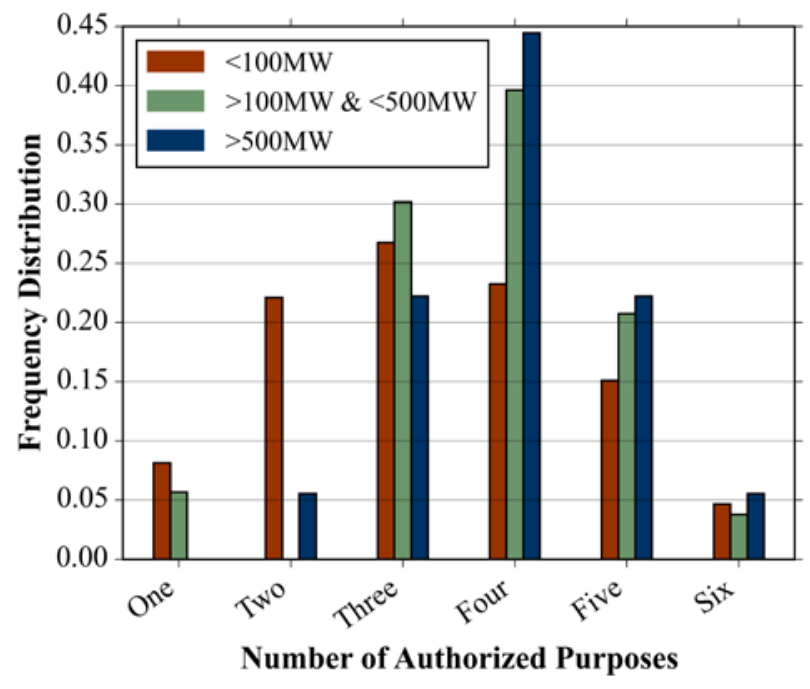

Figure 2 - Frequency distribution of authorized uses based on installed hydropower capacity. 
Impounding reservoirs are often called multipurpose reservoirs because they consistently and reliably meeting the diverse needs of both competing and complimentary stakeholders. To value a multipurpose project as a whole, the benefits of each purpose should be quantifiable. From an economic perspective, this is most readily achieved for energy-related services. Power is generated and sold in a regulated market, where monetization is achieved through a market-driven pricing mechanism. Ancillary service benefits are also clearly identified, as their economic contributions to electric power markets have been isolated and quantified since the Energy Policy Act of 1992. Many non-energy-related benefits, on the other hand, are often overlooked in the context of hydropower multipurpose reservoir use. When these benefits are monetized their economic value often surpasses that of power generation (IWR, 2013), contributing substantially to local economies and affecting millions of people.

The following research is a first attempt at defining a base case of the economic benefits of federal multipurpose hydropower reservoirs. The goal of this study is to inform stakeholders and the general public about the significant socio-economic benefits of multipurpose reservoirs, as well as provide hydropower developers and operators worldwide with an awareness of how the benefits of reservoirs in the U.S. are distributed across multiple uses. 


\section{METHODOLOGY}

There are six data categories that structure the multipurpose benefits framework. These categories are referred to herein as "uses", and they represent a culmination of operations and services made possible due to existence of a reservoir. These uses are broadly classified to identify categories associated with a reservoir project, and serve as a foundation for assessing collective and inter-dependent relationships:

1. Hydropower: Operation and use of generating facilities and/or equipment for producing power by the sole source of water.

2. Flood Control: Dams that facilitate the prevention and/or lessen the severity of flood damage to valuable resources within a flood basin.

3. Navigation: The operation and control of locks to facilitate the transportation of goods via inland waterways.

4. Recreation: The use of water bodies (reservoirs or rivers) for physical and recreational activities (boating, fishing, swimming, etc.).

5. Water Supply: Public and private withdrawals of water used for consumption, municipal, and industrial needs.

6. Irrigation: The withdrawal and use of water from reservoirs to meet the needs and requirement for crop and plant irrigation to sustain growth and production.

Uses can be complementary, as in the release of minimum flows to sustain navigation draft, aquatic health, and recreation activities, competing, when hydroelectric generation is foregone to manage reservoir levels for flood control by releasing spillway flows, or inter-dependent, as in the release of deep, cool reservoir water through hydropower turbines for use downstream in thermoelectric operations.

Each of these uses may have valuable inter-dependent economic benefit. Within a multipurpose benefits valuation framework, however, each unique use is often identified and valued individually. The challenge inherent to this methodology is that water is consumed both on-stream and off-stream, it is valued explicitly and implicitly, and valuation metrics are often not comparable across uses. In some instances, e.g. hydropower generation from a given volume of water, the use is easily monetized and quantified based on measurable units. Flood control benefits are valued based on the avoidance of costs or damages, and beneficiaries do not pay an explicit market price for the advantage of not incurring property loss during floods. Any approach to value all uses of a multipurpose reservoir will trade generality for a loss of specificity, which may lead to over- and undervaluation of benefits at certain reservoirs with important secondary and tertiary benefits. In order to address these issues and map out a framework for identifying a representative methodology that appropriately values all benefits, a foundational analysis is needed that represents a base case of economic benefits. This report seeks to establish an order of magnitude base case estimate that captures the cumulative benefits distribution across all federal reservoirs. 
Though previous studies have been conducted to quantify the economic benefits of multipurpose reservoirs (see e.g., Pizzimenti et al., 2010; Bray et al., 2011), these have been targeted at individual reservoirs or a particular utility or region of the country. The USACE provides a comprehensive valuation methodology in their annual Value to the Nation report, which quantifies the economic benefit of their civil works programs (IWR, 2013). Among the services they provide, flood risk management, navigation, water supply, hydropower, and recreation are quantified in terms of a Net Economic Benefit (NEB), as well as tax revenues generated for the U.S. Treasury. On an international level, Electricité de France (EDF), in partnership with the World Water Council (WWC), released a report as part of their Multipurpose Water Uses of Hydropower Reservoirs framework which highlighted the economic benefits of twelve multipurpose reservoirs around the globe (Branche, 2015). Despite these comprehensive evaluations, a scalable valuation methodology for all multipurpose hydropower reservoir benefits has yet to be presented on a national level.

The main objective of a federal water resources project is to contribute to National Economic Development (NED). Methodologies for performing NED cost-benefit analyses are outlined in the Economic and Environmental Principles and Guidelines for Water Resources Implementation Studies (P\&G), published in 1983 by the U.S. Water Resources Council to provide guidance in evaluating potential federal water resources projects and their alternatives. The P\&G has been used since then by USACE, USBR, and TVA. The idea is that a water resources project's NED benefits, or increases in the value of the national output of goods and services following project implementation, must exceed its cost, thus justifying federal investment in the project. NED benefits can be expressed as society's willingness to pay, as is the case with the sale of hydropower generation or the lease of water for M\&I purposes, or it could be analyzed from a costs-avoided perspective, used when looking at the benefits of flood control structures. If a project has been authorized by Congress for one or more uses, the NED analysis has to consider all purposes in order to ensure that marginal benefit of use exceeds marginal cost of supply, and that marginal benefit per unit of water (or reservoir storage) is equal across uses (McMahon et al, 2001). An updated set of Principles, Requirements, and Guidelines (PR\&G) was released in December 2013. It includes changes that promote decision making across the Federal Government to be transparent and well informed. Access to a more comprehensive approach to water projects will maximize economic, environmental, and recreational benefits by allowing communities to pursue these issues and priorities on a local level. The effect of this is expected to encourage more efficient and thoughtful uses of reservoirs which may act to redistribute percentage type uses in general.

The primary advantage of quantifying benefits in terms of an NED approach is twofold. First, market transactions like hydropower, and non-market transactions including recreation, are valued using measurable financial units that reflect an increase in the national output of goods and services. Second, the principles of NED evaluation represent the federal perspective, rather than region specific valuations, and allow the benefits of the multipurpose reservoirs across the nation to be compared evenly. This advantage, as noted above, may oversimplify the benefit dynamics at certain reservoirs with numerous interdependent benefits. For example, the decision to build a manufacturing plant near a river may be driven by the proximity to cheap inland navigation and the improved transportability of physically large products. The local manufacturing benefits and economic impacts are a direct result of the lock, but these benefits are not easily identified or captured in a value analysis. The weighted effects of secondary economic benefits will be the subject of future research. 
Three federal agencies, USACE, USBR, and TVA, own and operate $42 \%$ of the installed capacity of the U.S. hydropower fleet, including Pumped Storage Hydro (PSH). Raw data relating to NED-type benefits valuation was requested from each agency for the six benefit categories. Because various economic evaluations are employed by each agency in their proprietary cost-benefit analyses and annual reports, additional data analysis was completed before NED benefits could be quantified and compared across agencies. Further, data collected from an agency may cover project, unit, or division level operations, and it may represent the aggregate of multiple reservoirs, of which only a fraction possess hydroelectric generating capability. Additional research, literature review, data collection, and methodology development were completed to allocate larger-scale data to individual reservoirs.

Based on the availability of both public and proprietary data, the following represent the methodologies used to compute the economic benefit of each multipurpose use.

\subsection{POWER GENERATION}

To quantify hydropower generation, the total annual kilowatt-hours of energy production from a power plant is multiplied by the average wholesale rate at which it is sold. For TVA, power is sold directly to utilities or other customers in contrast to federal hydropower, where power marketing administrations ${ }^{1}$ actually sell power delivered by USACE and $\mathrm{USBR}^{2}$. Depending on their business model, each agency provided an average rate for either an individual plant or a group of plants. The unit price for energy varies between and within the agencies as they cater to different regions of the nation, each with unique energy markets and demand. This current preliminary analysis does not include the value of capacity or ancillary services, which could further differentiate the distribution of overall hydropower benefits.

\subsection{NAVIGATION}

Inland navigation in the United States is responsible for the transportation of over 500 million tons of cargo every year. The inland waterway system, consisting of 192 lock sites and 235 chambers, extends through 12,000 miles and touches 38 states. A total of 68 of the 192 locks are located at powered dams (Figure 3). Inland navigation serves a vital role in the transportation of goods throughout the U.S. The USACE maintains and operates the majority of navigation infrastructure on inland waterways and records usage statistics at the Waterborne Commerce Statistics Center (WCSC). The WCSC provided essential data3 needed for the 68 locks located at multipurpose hydropower reservoirs to calculate the NED navigation benefit. This benefit is manifested as shipper savings (S.S), or the amount of money saved by shippers who send commodities by barge (typically the cheapest shipping option) rather than by truck or rail (usually the second least expensive option). A national value of S.S. was provided by the Planning Center of Expertise for Inland Navigation.

1 Power marketing administrations generally set cost-based rates which are typically lower than the next-best alternative source of electricity. If hydropower had been valued as the avoided cost for the receiving utilities, the benefit would likely be higher.

2 For purposes of the current work, it is recognized that the "rates" used herein for the hydropower benefit determination for TVA versus the other federal agencies are derived differently, and that actual confidential data associated with power sold by utilities or the power marketing administration may suggest higher retail values than reported in the current analysis.

3 http://www.navigationdatacenter.us/data/data1.htm 


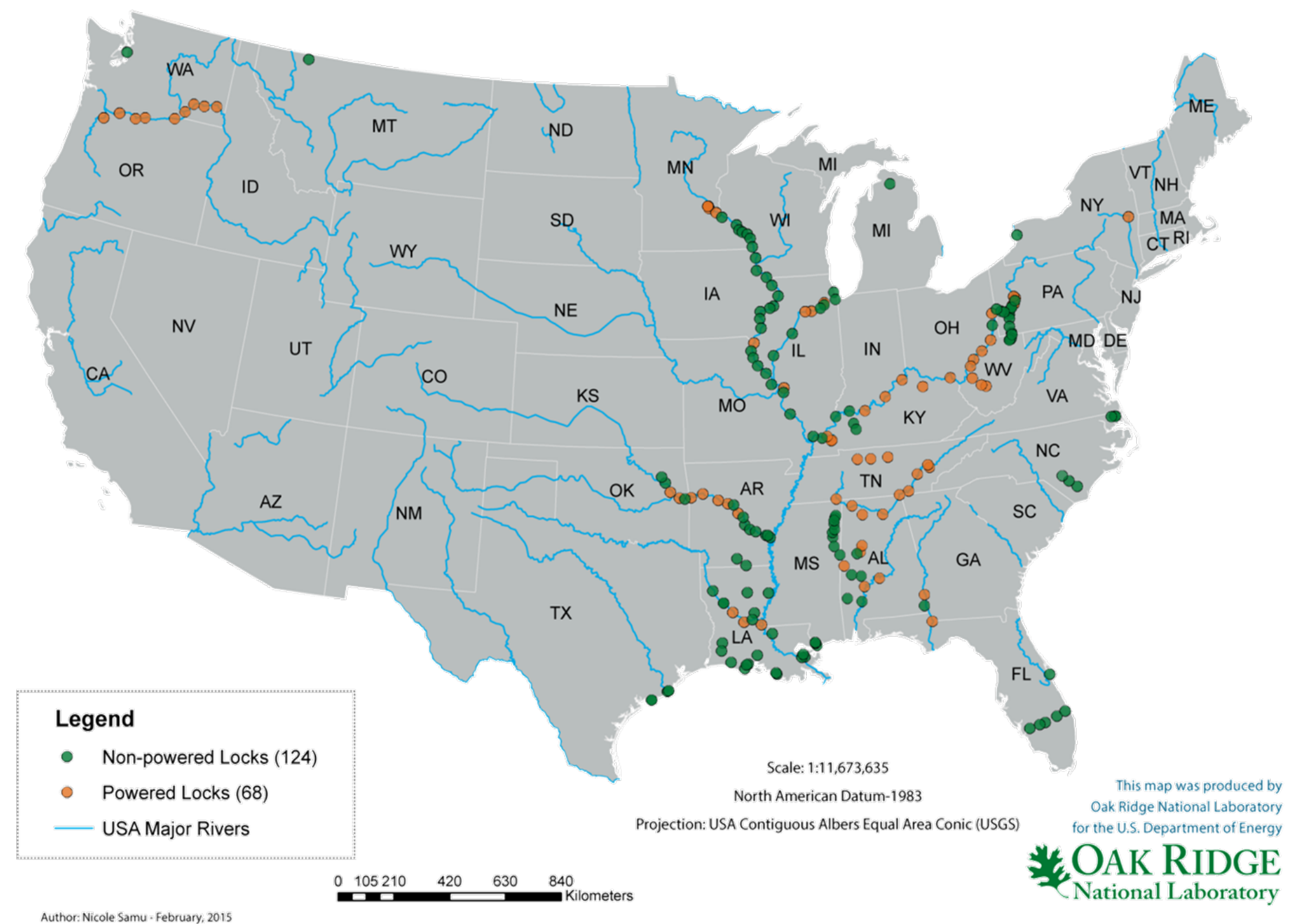

Figure 3 - Map of all powered and non-powered navigation locks in the United States. 
To estimate the NED navigation benefit, the tonnage passed through a powered lock is multiplied by the national S.S. value. The S.S. units are given in dollars per ton, reflecting the dollar value saved over the entire length of a shipment. A typical shipment passes through multiple locks and, consequently, the raw tonnage value at each lock cannot be used directly to estimate the navigation benefit as it would result in double counting over the trajectory of a shipment. In an effort to eliminate the double counting of goods passing through multiple locks, the individual lock tonnage is divided by the total tonnage passed through all locks. This fraction of the national tonnage is multiplied by the national reduced tonnage (i.e. the total tonnage without double counting), provided by IWR, to arrive at an annual lock tonnage that excludes double counting. This tonnage is multiplied by the national S.S. to generate the NED navigation benefit for each lock.

\section{$2.3 \quad$ FLOOD CONTROL}

Flood control benefits are quantified as damages avoided, or the reduction in potential or realized damages to structures, contents of structures, and land use in areas that would have been inundated had the structure not been in place. Flood plain curves, using geographic and local data, allow both the acreage and depth of a prevented flood to be estimated. When a dam regulates a flooding event, the volume stored is used in the flood plain model. A fraction of the value of land, buildings, goods, and activities that lie within the flood plain and would have been destroyed are assigned to the flood event based on its severity. This ultimately allows a dollar amount of potential damages to be reached.

Since the benefit for preventing these natural events can be substantial, each agency performs a proprietary analysis to estimate damages avoided based on derived flood-stage-damage relationships for particular regions. This value is commonly assigned to an entire river system or agency project incorporating the flood benefits of multiple reservoirs with and without hydropower. To obtain the benefit from a single reservoir, the fraction of total system flood storage provided by an individual reservoir is multiplied by the damages prevented. In most cases cumulative damages for the past fifty years were provided, and the benefit was calculated as an average annual benefit. In some cases the benefit was obtained from publicly available annual reports, system-wide flood studies, or district level presentations.

\subsection{RECREATION}

Reservoirs are popular destinations for a wide variety of recreation activities including fishing, boating, camping, swimming, water sports, and wildlife observation. Three common procedures are available to estimate recreation spending: the travel cost method (TCM), the contingent valuation method (CVM), and unit day values (USACE, 2000). TCM models assume the travel and time costs spent by visitors to get to a reservoir increase with distance. A demand curve is derived that values the reservoir using travel and time as 'price' surrogates. The CVM relies on surveys that ask an individual their willingness to pay for recreation activities (for which they are not currently paying) at a given location. The unit day value approach assumes the total benefit of the reservoir can be estimated by multiplying the number of visitors to the reservoir by the average amount spent per visitor per trip. Visitation data is produced from surveys and regional economic and population models, while spending profiles are generally obtained via direct survey (USACE, 2000; Black, McKenney, Unsworth, \& Flores, 1998). 
To estimate the economic benefit of recreation, most agencies rely on the unit day value approach, with visitor counts to reservoirs and related recreation areas obtained through an agency survey or provided by state and national park services. In this report, the economic benefit of recreation is computed by multiplying the number of annual visitors to a reservoir by a daily spending average. In most cases either the average spending amount or the number of visitors contain regional and temporal multipliers to capture spending trends in a specific region and account for the amount of time each visitor participates in recreation activities. Common spending amounts range from $\$ 10 /$ visitor/day for local visitors participating in day use activities like birdwatching or hiking, to $\$ 40 /$ visitor/day or more non-local visitors participating in leisure or multi-day recreation activities, including water sports and overnight camping (Synes, 2005; Stynes and Chang, 2007; Cardno Entrix, 2011; Chang et al., 2012; White et al., 2013).

Most recreation data represent an estimate based on trends observed at sites around the country. When survey data are not available at a particular site, it is common for agencies to estimate a number for that site based on other national recreation areas with similar characteristics. This approach, in combination with the diverse activities and preferences of recreationists at reservoirs, lends itself a great deal of uncertainty in number of visits and spending amounts per activity. In a pure economic benefits analysis, this uncertainty cannot be easily quantified. To mitigate the uncertainty in a national level analysis, the approach used in this report restricts valuation to two metrics and relies primarily on data provided by individual agencies.

\subsection{MUNICIPAL WATER SUPPLY}

Approximately 62 billion gallons of water per day are used for public, municipal, and industrial uses in the U.S. (excluding mining and livestock), accounting for $17 \%$ of total surface- and groundwater withdrawals (Maupin et al., 2014). Many multipurpose reservoirs assign a percentage of their total storage to water supply and are equipped with facilities to release or withdraw stored water. In 2011, approximately 35\% of USACE multipurpose reservoirs included a water supply purpose (IWR, 2013).

In general, federal agencies like USACE and USBR value a water supply reservoir use by multiplying the total amount of water supplied by an average price of water (IWR, 2013; DOI, 2014), yielding a dollar value per acre-ft of water. When this data is not available on an annual basis, historical prices are indexed to present day values or use estimates. Baked into this value is both the cost of procuring an alternative water supply, and the cost of maintaining and building infrastructure to deliver the water supply to end users (Pizzimenti et al., 2010).

To produce the NED benefit of M\&I uses, the volume of water stored for municipal and industrial use is multiplied by the national average price of water per unit volume. In general, contractors and municipalities reserve a volume of water under contract to be made available each year for their consumption. This data are largely found within project operating plans that outline the storage allocations of each reservoir, or in public reports on water use (see TVA 2012). 


\subsection{IRRIGATION}

Most of the irrigated farmland in the U.S. sits west of the Mississippi River, where water is procured and distributed for irrigation largely by USBR through the Department of the Interior (DOI). The irrigation benefit is pronounced in arid regions where lower rainfall necessitates irrigation infrastructure such as pumping stations, diversion dams, and canals. These systems are capable of transporting stored water from a reservoir to farmland anywhere from less than a mile to hundreds of miles away.

The NED benefit for irrigation is quantified by multiplying the total acres of land irrigated by the value of crops grown on those acres. An estimate of crops produced is developed using geographic information system (GIS) imagery to map the type and acreage of crops that benefit from USBR supplied irrigation water. A total dollar value is obtained by combining crop yield data from the state level with nationwide crop prices supplied by the U.S. Department of Agriculture (USDA). These values were provided by USBR, which keeps yearly data on the number of acres, types of crops, and regional value of those crops for each of their projects authorized for irrigation.

\subsection{METHODOLOGY LIMITATIONS}

While the results are presented largely as point estimates, it is important to note that significant engineering judgement and interpretation have been applied at all levels of the data analysis and collection, and many estimates contain a high level of uncertainty. In cases where the only available data for a multipurpose reservoir was hydropower generation, the reservoir was omitted from the analysis. In some instances data for one or more of the authorized uses were not available; in such cases, reservoirs were left in the analysis only if data for at least two uses were present. Pumped-storage hydropower plants were also excluded due to the increased complexity of valuing power generation benefits. After these exclusions, the analysis captured 40 (USBR), 72 (USACE), and 27 (TVA) conventional hydropower plants representing 95\%, 99\%, and 99\% of federal agency conventional installed capacity, respectively.

Supporting data have been procured over the course of a year from a variety of sources, reports, and discussions. An annual comparison of economic benefits, given the temporally disparate nature of the available data, is not possible. Many data sets are not published until years after the period of analysis (e.g., consumptive water use in the Tennessee Valley), while some data are easily obtainable after the end of the year (e.g., hydropower generation and electricity rates). Still others (e.g. damages avoided due to flood control projects) are given as a single cumulative estimate spanning the life of the project. The results of the hydropower multipurpose reservoir benefits analysis are presented with these caveats in place to develop a base case from which future refinements can be rendered. 


\section{RESULTS AND ANALYSIS}

The hydropower multipurpose reservoir benefits analysis is presented in two sections: the individual and combined results of all federal agency reservoirs, and an individual case study of the Cumberland River system hydropower projects, which are owned and operated by USACE.

\subsection{FEDERAL AGENCIES}

The benefits distribution of multipurpose hydropower reservoirs at each federal agency is presented in Figure 4. TVA and USACE reservoirs show a similar benefits structure, with recreation comprising the largest overall benefit (nearly $40 \%$ of the total economic benefit) and navigation providing the smallest benefit ${ }^{4}$. Power generation provides between $25 \%$ and $15 \%$ of the total benefit, ranking as the second and third largest benefit for TVA and USACE, respectively. USACE hydropower reservoirs show a small but notable increase in flood control and water supply benefit over TVA. Nearly $73 \%$ of USACE multipurpose hydropower reservoirs are authorized for flood control compared to $79 \%$ for TVA. Though TVA has a higher percentage of reservoirs providing flood control, the benefit is slightly less per reservoir, with the difference being made up in navigation and power benefits. A significant departure in benefits distribution is seen with USBR reservoirs, where $60 \%$ of the economic benefit is tied to irrigation. USBR dams are predominantly located in the western U.S., where irrigation is the primary source of water for many farmers and an authorized use for nearly all reservoirs. The remaining representative benefits are nearly equally distributed amongst power, water supply, and recreation.

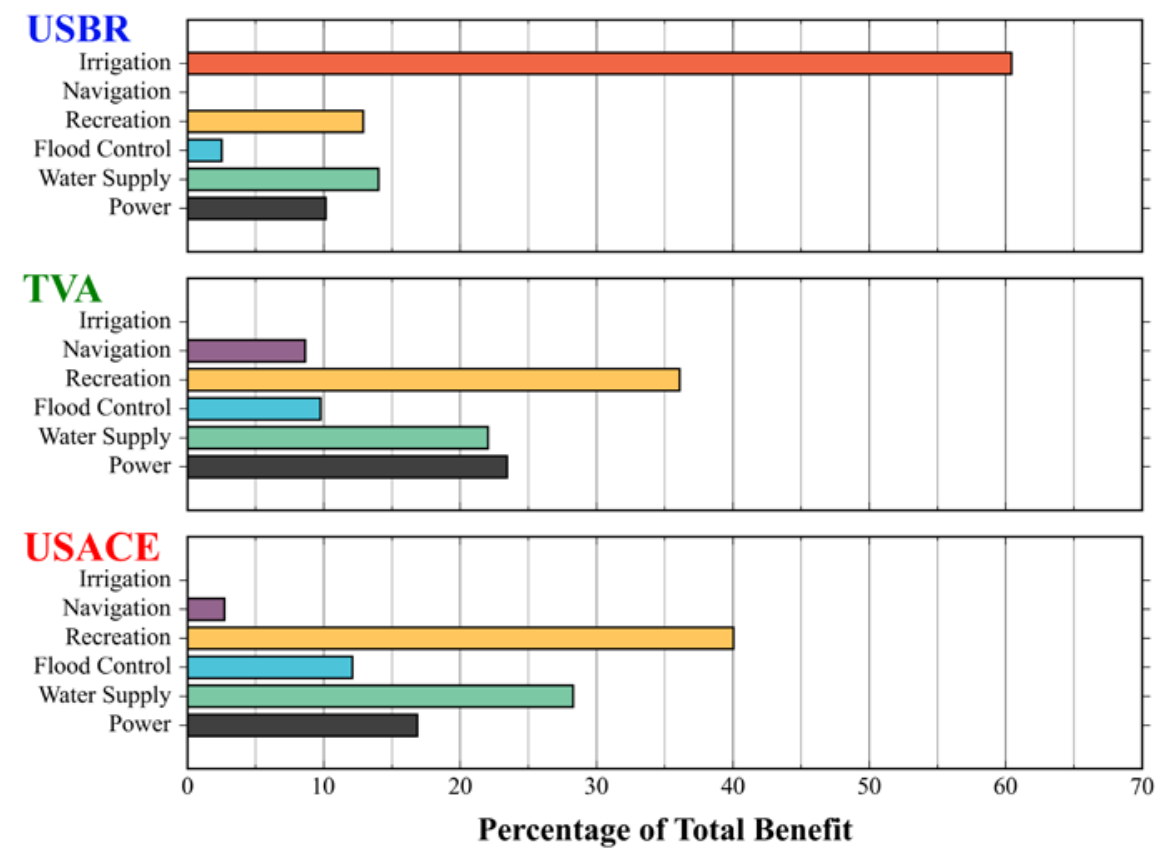

Figure 4 - Distribution of economic benefit per use per agency.

4 While a total of 16 USACE multipurpose hydropower reservoirs are authorized for irrigation, no data was available to quantify any irrigation benefit. 
As the number of quantifiable purposes of a reservoir increases, the respective percentage of power benefit decreases based on installed capacity (Figure 5). For reservoirs with two purposes, the hydropower benefit increases significantly with installed capacity. Very large plants with $>500 \mathrm{MW}$ of capacity provide the substantial majority of economic benefit when there is only one other quantifiable benefit. This trend is also prevalent for reservoirs with three purposes. For reservoirs with four and five purposes, hydropower tends to provide a slightly disproportionately smaller percentage of the total benefit in most cases. This is interesting to note in the context of Figure 2, which shows that as installed capacity increases, the number of authorized purposes tends to increase. Reservoirs with installed hydroelectric capacity of less than 100MW tend to have fewer quantifiable uses, and hydropower tends to make up a smaller portion of the total benefit. On the other end of the spectrum, large hydroelectric dams are also more likely to be part of a large multipurpose project. The greater the number of alternate purposes, the smaller the representative contribution of hydropower towards the total benefit.

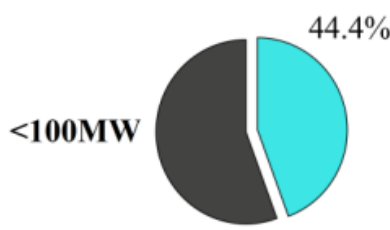

Two
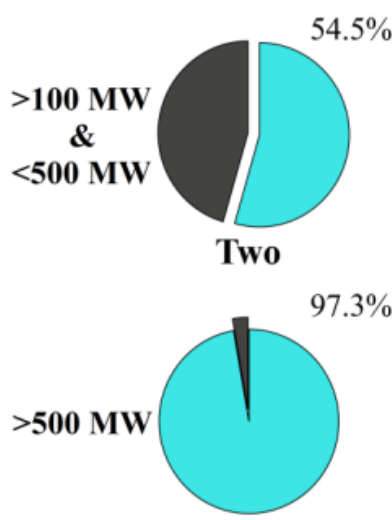

Two

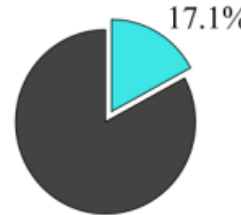

Three

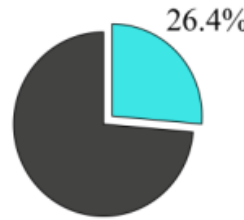

Three

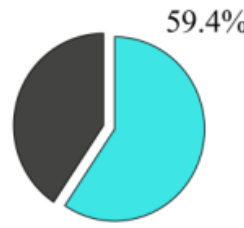

Three

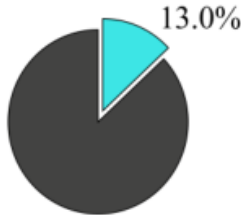

Four

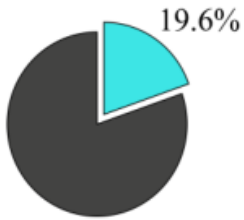

Four

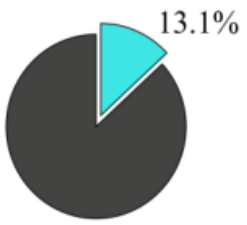

Four

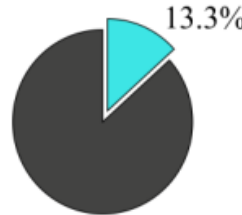

Five

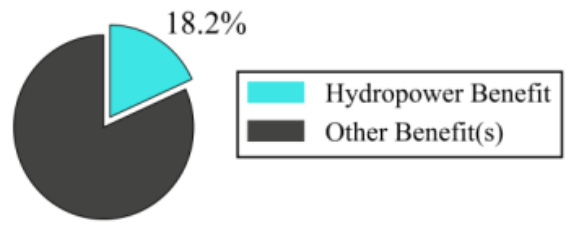

Five

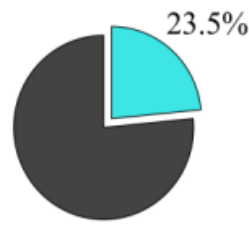

Five

Figure 5 - Average percentage of power benefit per reservoir. Columns depict the number of quantifiable purposes, while rows represent a range of installed capacity.

The benefits structure of multipurpose hydropower reservoirs varies with installed capacity (Figure 6). As installed capacity decreases from 500MW to less than 100MW, the economic benefit of power generation as a portion of overall benefits is reduced $50 \%$. This is attributable both to a decrease in revenue from power generation and the relative increase in the benefit of additional purposes. Notable is recreation, which tends to increase as a benefit as installed capacity is reduced. Many reservoirs with low to mid-size installed capacity are characterized by substantial miles of shoreline and surface area that consistently attract a variety of recreationists. When these reservoirs are located close to metropolitan areas, the recreation benefit can make up a large majority of the overall reservoir benefit (Hadjerioua et al., 2015). 


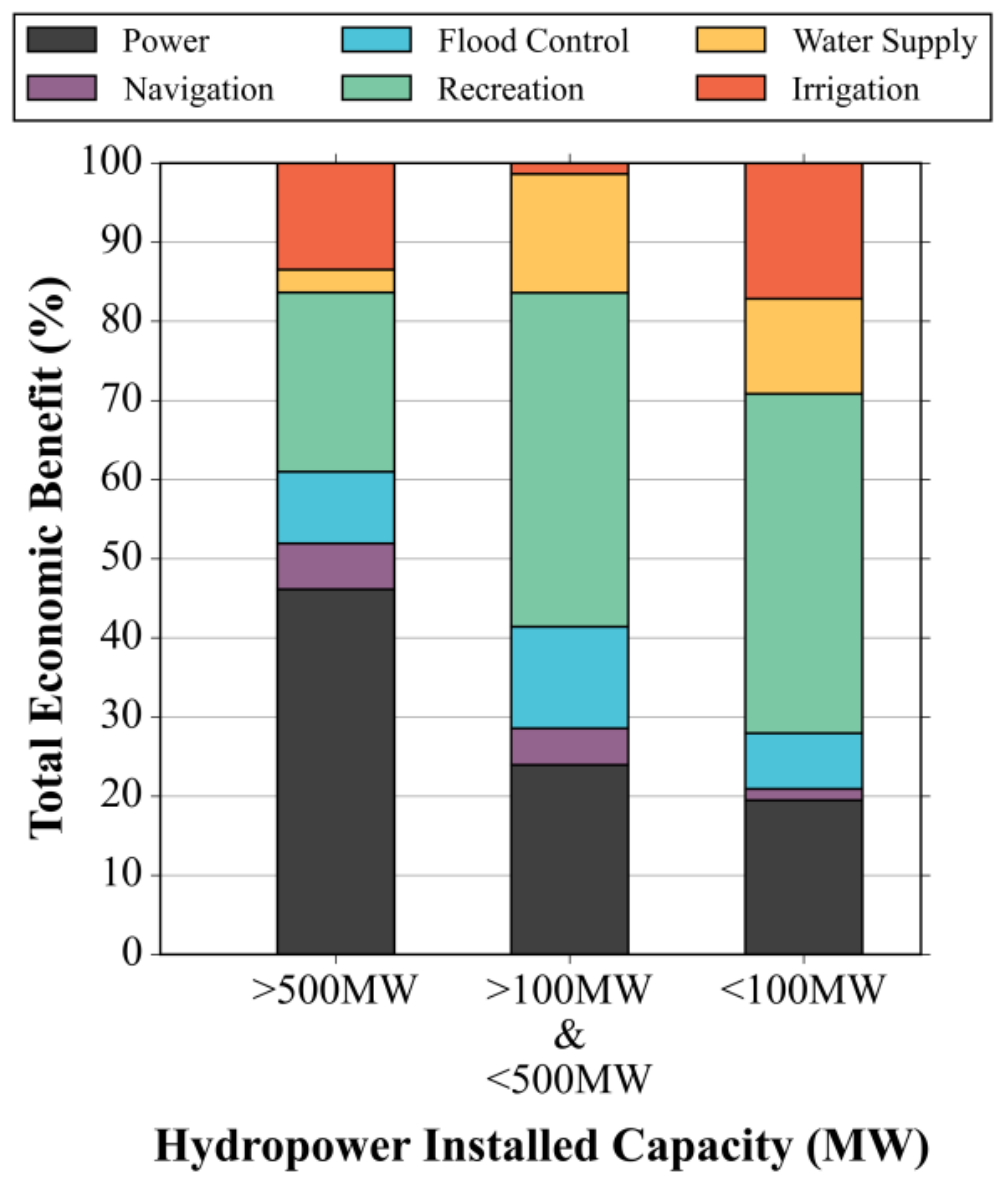

Figure 6 - Breakdown of economic benefits by installed capacity.

Flood control and navigation benefits tend to contribute less to the overall reservoir benefit as installed capacity is reduced. The navigation benefit is tied directly to the tonnage of commodities shipped through a lock, which correlates with the width of the lock and the ability of a river to physically support barge traffic. It follows that larger rivers with greater hydropower potential also provide the largest navigation benefit. The flood control benefit is also intuitively linked to dam size, as the ability to store surface water and mitigate natural disasters also translates into the ability to store large amounts of water for hydroelectric generation. Water supply and irrigation do not show any readily apparent trends in relation to installed capacity. These benefits are largely location dependent, where proximity to water consumers is a driving factor in benefits distribution.

The relative weighting of the hydropower benefit compared to alternate multipurpose benefits is shown in Figure 7. In each figure, the size of the points represents installed capacity at the individual reservoir. Several observations provide insight into the dynamics of benefit distributions based on hydropower plant characteristics. The hydropower benefit is much larger than the recreation benefit for run-of-river dams with large installed capacity (Figure 7, top left). The recreation benefit tends to dominate most dams with smaller relative installed capacity, while peaking dams with larger installed capacities tend to group towards the bottom left, where both hydropower and recreation benefits are small. Many larger peaking dams show a substantial irrigation benefit (Figure 7, bottom left). These dams tend to be located in the 
western U.S., with large storage capacity that is used primarily for agriculture. Few run-of-river dams have substantial capacity to provide a significant irrigation benefit, and the ones that do trend towards a smaller installed capacity.
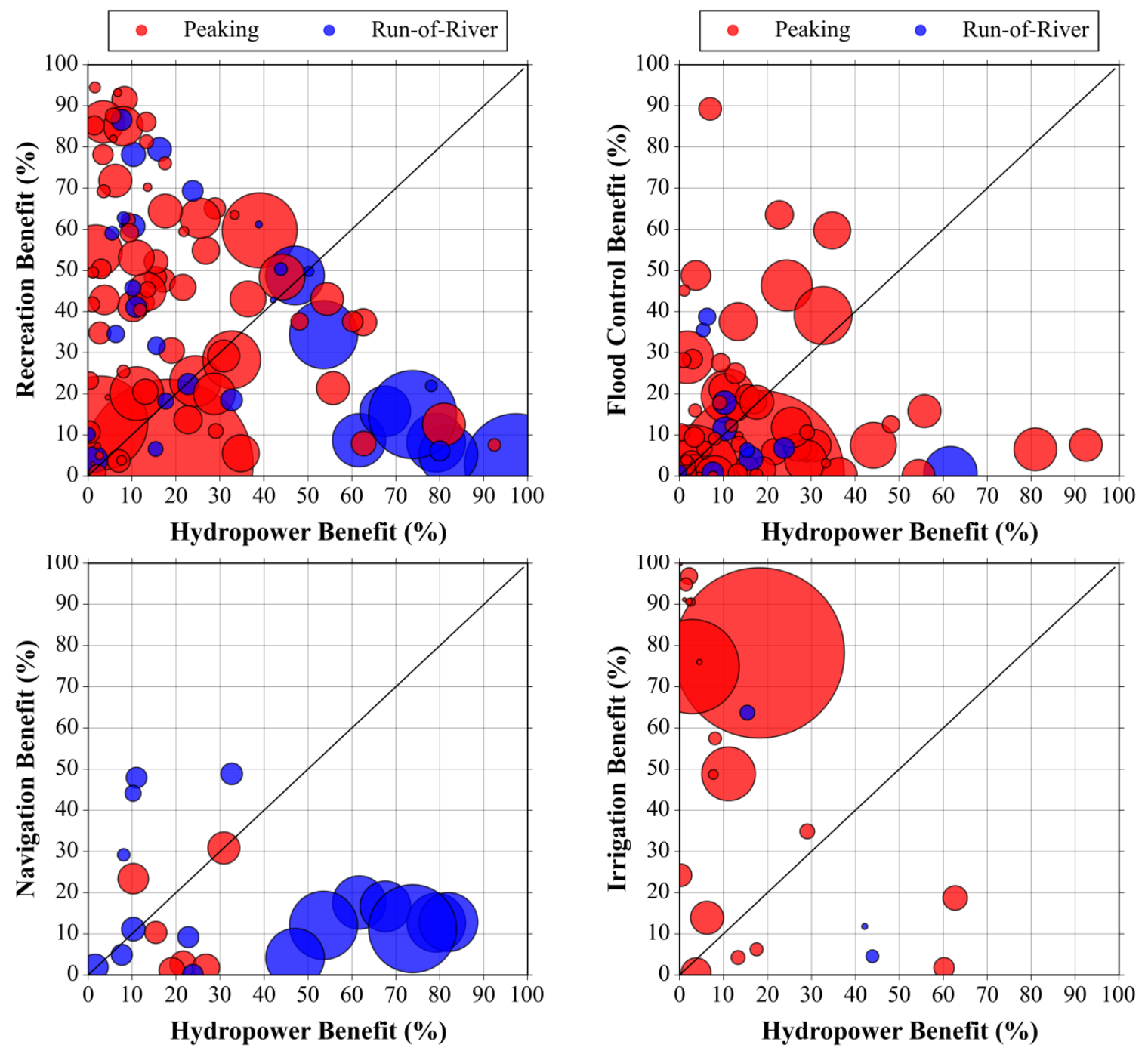

Figure 7 - Weighting of hydropower benefit versus an alternate multipurpose benefit. In each case, the solid black line indicates an even split between benefits. Any points below the line indicate the hydropower benefit is greater, while points above the line indicate the respective benefit is greater than the hydropower benefit. Points are colored by mode of operation (NHAAP, 2015) and sized by installed capacity.

The weighting of flood control benefits versus hydropower benefits (Figure 7, top right) shows a grouping near the lower left corner where both purposes represent a small percentage of the total benefit for the full spectrum of installed capacity. Only a handful of peaking or storage dams show a flood control benefit greater than $50 \%$ of the total benefit. Many dams with the smallest installed capacities show a slight but notable trend towards flood control benefits over hydropower benefits. The navigation benefit is dominated by run-of-river dams, many of which have larger installed capacities (Figure 7, lower 
left). Most of these dams are located in the Pacific Northwest, where high flows and wider rivers increase the weighting of the hydropower benefit over navigation. In the southeastern U.S., the navigation benefit increases for run-of-river dams that are located on smaller rivers near regions with notable barge traffic.

Due to prominent differences in geography, population, and climate in the Eastern and Western U.S., the priorities and benefits distribution of multipurpose reservoirs tend to exhibit geospatial variation. Figure 8 compares the distribution of the economic benefits of reservoirs located in the East versus those in the West, using the Mississippi River as the dividing line. The share of benefits from power generation and flood control is similar in both regions, representing approximately $15 \%$ and $8 \%$ of the total economic benefit, respectively. Navigation has a notably higher economic benefit in the East, attributable to locks on three major U.S. Rivers (Tennessee, Ohio, and Mississippi) that maintain connectivity between populous industrial regions. The recreation benefit in the East shows a nearly three-fold increase over that in the West at the expense of irrigation and water supply benefits. Recreation benefits in the East tend to be greater than those in the West due to their proximity to large populations, as opposed to the more remote and isolated nature of many mountainous western reservoirs. As previously discussed, irrigation is a primary reservoir use in the West, justifying the large percent of total benefits compared to eastern reservoirs. It should be noted that irrigation was not analyzed in USACE and TVA reservoirs due to insufficient data, thus the lack of irrigation benefit.

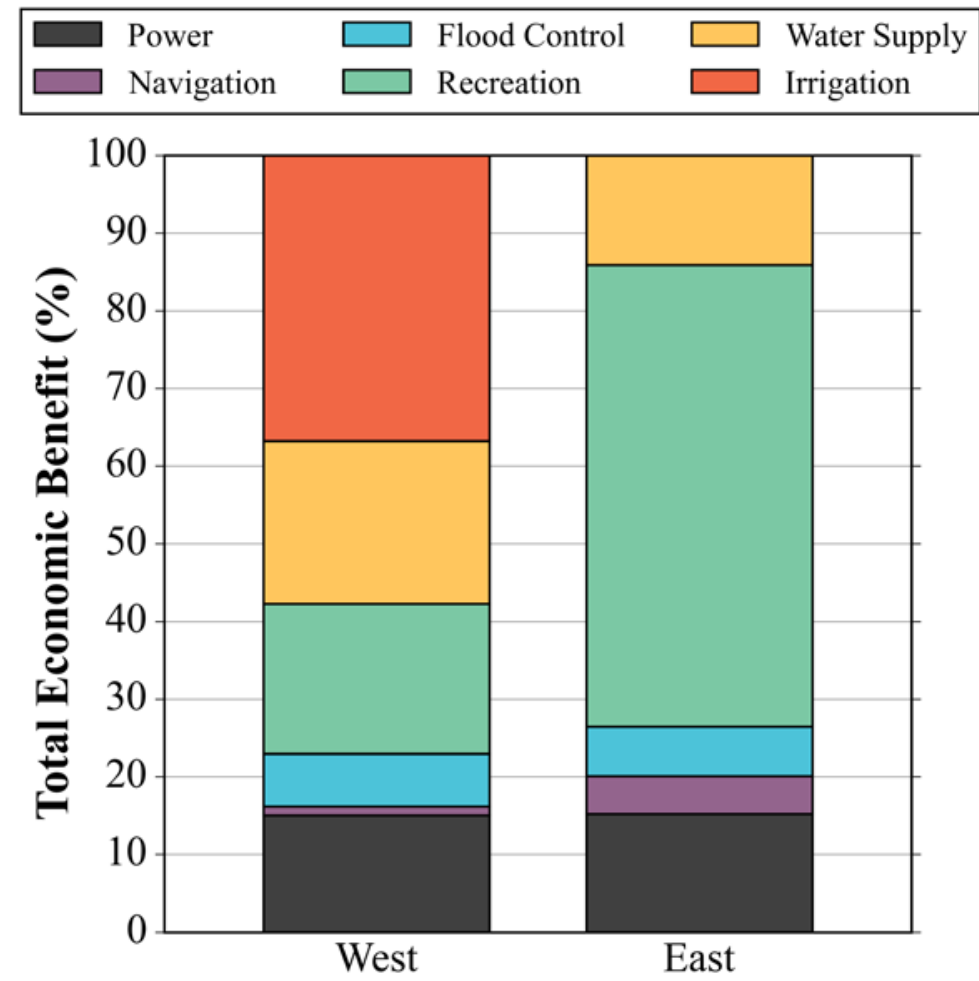

Figure 8 - Distribution of the economic benefits of multipurpose reservoirs in Western versus Eastern U.S. 


\subsection{USACE: ALL CIVIL WORKS VS. HYDROPOWER PROJECTS}

The Institute for Water Resources (IWR) produces an annual report that estimates the value to the nation produced by the USACE Civil Works programs (IWR, 2013). The economic benefits are given both as contributions to NED and as revenues to the U.S. Treasury. The Civil Works programs includes dams, levees, dikes, reservoirs, and other infrastructure dedicated to water resource management for the purposes of flood risk control, inland navigation, coastal navigation, water supply, hydropower, and recreation. Many of these non-hydropower reservoir infrastructure projects have substantial benefits lumped into the analysis. To isolate the benefits of multipurpose hydropower reservoirs, the results from all USACE hydropwoer projects were combined and compared to the total benefits from the USACE Civil Works (Figure 9). As a reference, USACE operates and maintains nearly 700 dams throughout the U.S., and over $10 \%$ are equipped with hydropower capabilities (75 total hydropower projects).

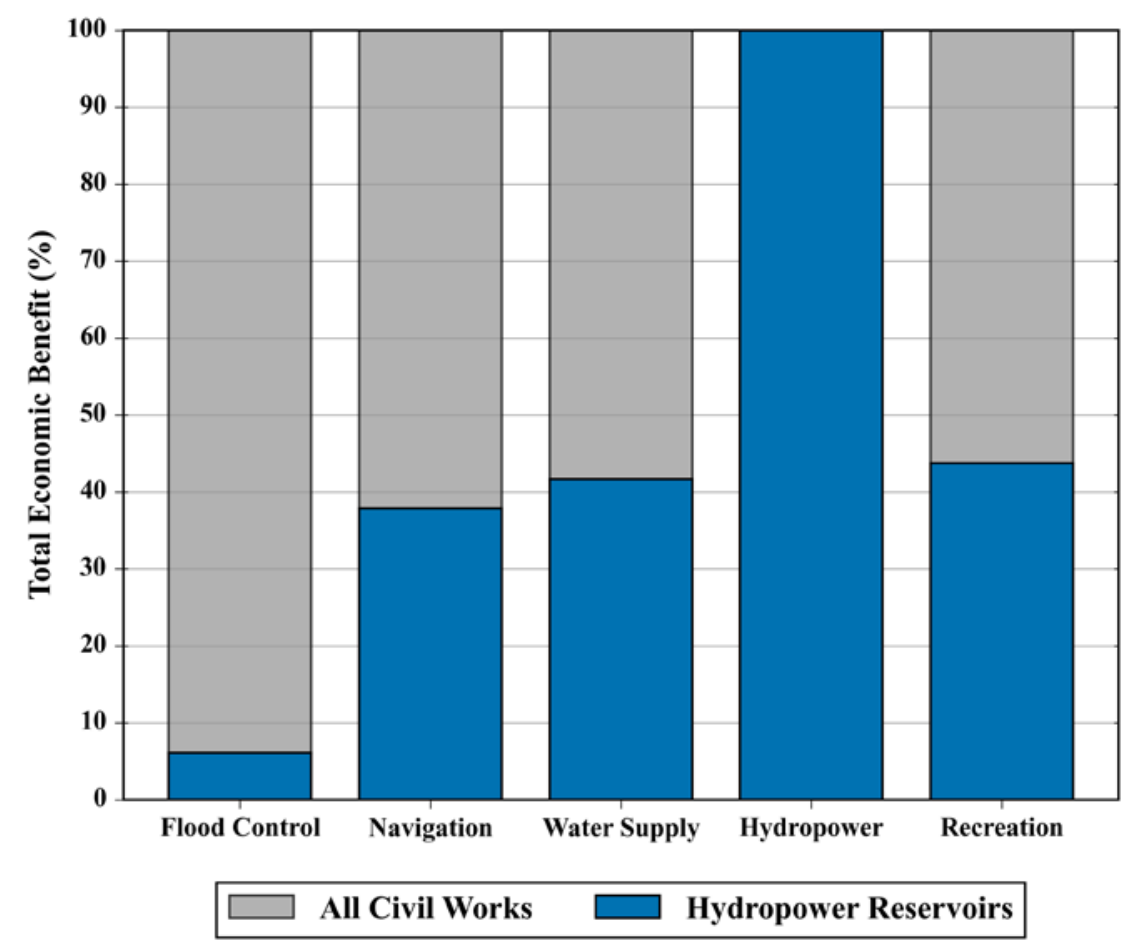

Figure 9 - Annual USACE hydropower economic benefit compared to the 2010 annual economic benefit of all USACE Civil Works programs.

As expected, hydropower reservoirs account for all of the hydropower benefit. Nearly half of the total recreation benefit is supplied by hydropower reservoirs, highlighting the often strategic location of multipurpose reservoirs near population and, consequently, load centers. The flood control benefit is comprised almost entirely of non-hydropower dams, reflecting the fact that flood control is commonly the primary authorized use of a non-hydropower dam. It is evident that USACE hydropower projects provide numerous and substantial benefits despite representing only $10 \%$ of the dam fleet. 


\subsection{CUMBERLAND RIVER SYSTEM CASE STUDY}

The Cumberland River System reservoirs are ideal for a river system case study. The true multipurpose nature of all projects, the proximity of the city of Nashville to both the Cumberland River and two large reservoirs, and the quality data provided by the USACE Nashville District office offer compelling support for a multipurpose benefit valuation. In addition, all economic values are publicly available, though not easily found, centrally located, or presented in a standard format. The methodologies described in the previous section were used to quantify the economic benefits of each individual multipurpose reservoir based on data from 2012 obtained largely from the USACE Value to the Nation analysis ${ }^{5}$ (Figure 10). Each chart is placed at the corresponding geographical location from upstream to downstream.

The USACE, Nashville District, owns, operates and maintains nine multipurpose projects on the Cumberland River. Four locks operate on the main stem of the Cumberland River, transporting millions of tons of commodities such as coal, petroleum, crude materials and food and farm products to and from Nashville and neighboring counties. These areas also rely on eight flood control structures with total flood storage capacity of 5.5 million acre-ft. All nine projects have recreation as an authorized use. Common recreational activities on the Cumberland include fishing, hunting, camping, boating, picnicking, and hiking.

Recreation has the greatest economic benefit on the Cumberland River even though no reservoir was built for that purpose. Barkley, Cheatham and Dale Hollow dams were built for power generation, but hydropower actually resulted in the smallest NED benefits. The characteristics of mainstem and tributary reservoirs exhibit slightly different characteristics based on authorized purpose - all four main stem reservoirs operate locks for navigation, which contributes up to $29 \%$ of the total benefit (the navigation benefit of Cordell Hull is below $0.5 \%$ and thus did not appear on the chart). Cheatham and Old Hickory are not authorized for flood control, though Old Hickory has a small volume of flood storage capacity that is utilized as necessary. The three tributary reservoirs, J. Percy Priest, Center Hill, and Dale Hollow, in addition to Wolf Creek, have three primary benefits: recreation, flood control, and power generation.

The substantial percentage of recreation benefits as a portion of total project benefits warrants further discussion. The Cumberland reservoirs represent 9 out of 403 projects, or $2.2 \%$ of the total number of projects for which USACE estimates recreation benefits (USACE, 2014; IWR, 2014). The total number of visits per year to Cumberland reservoirs, 31.1 million, is approximately $9.3 \%$ of the national total of visitors to USACE projects. Old Hickory and J. Percy Priest rank as the $3^{\text {rd }}$ and $8^{\text {th }}$ most visited USACE project, respectively. These projects are located 16 and 12 road miles, respectively, from Nashville, which tallied an estimated population of 1.8 million as of 2013 (Census.gov, 2013). A total of 6 reservoirs in the Cumberland system are in the top 30 visited USACE projects (Figure 11). With the exception of Wolf Creek, all are within 120 road miles of Nashville. As road miles between Nashville and each dam decreases, there are some positive effects in terms of annual recreation visits to the reservoir (Figure 12). This trend is apparent in reservoirs that are closest and furthest from Nashville, while those between 50 and 150 miles exhibit a level recreation visitor rate of about 2.5 - 3.5 million per year.

5 http://www.corpsresults.us/ 


\section{ECONOMIC BENEFITS OF MULTIPURPOSE RESERVOIRS: \\ CUMBERLAND RIVER SYSTEM - 2012

(Not to scale. Percentages shown)

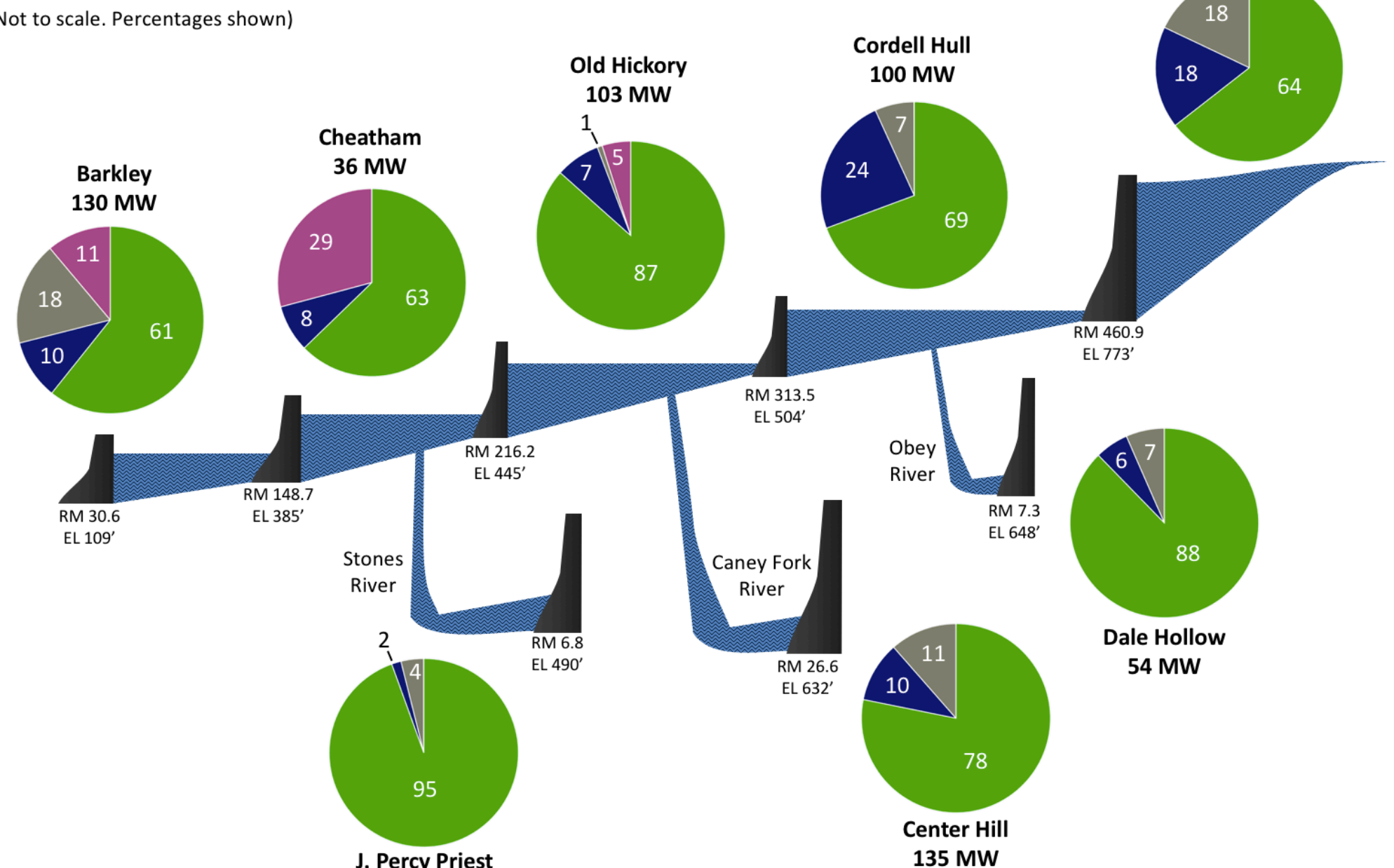

Navigation

Irrigation

Flood Control

Power Generation

Recreation

Water Supply

Figure 10 - NED benefits distribution of the Cumberland River System multipurpose projects. Spatial distribution of reservoirs is not to scale. 


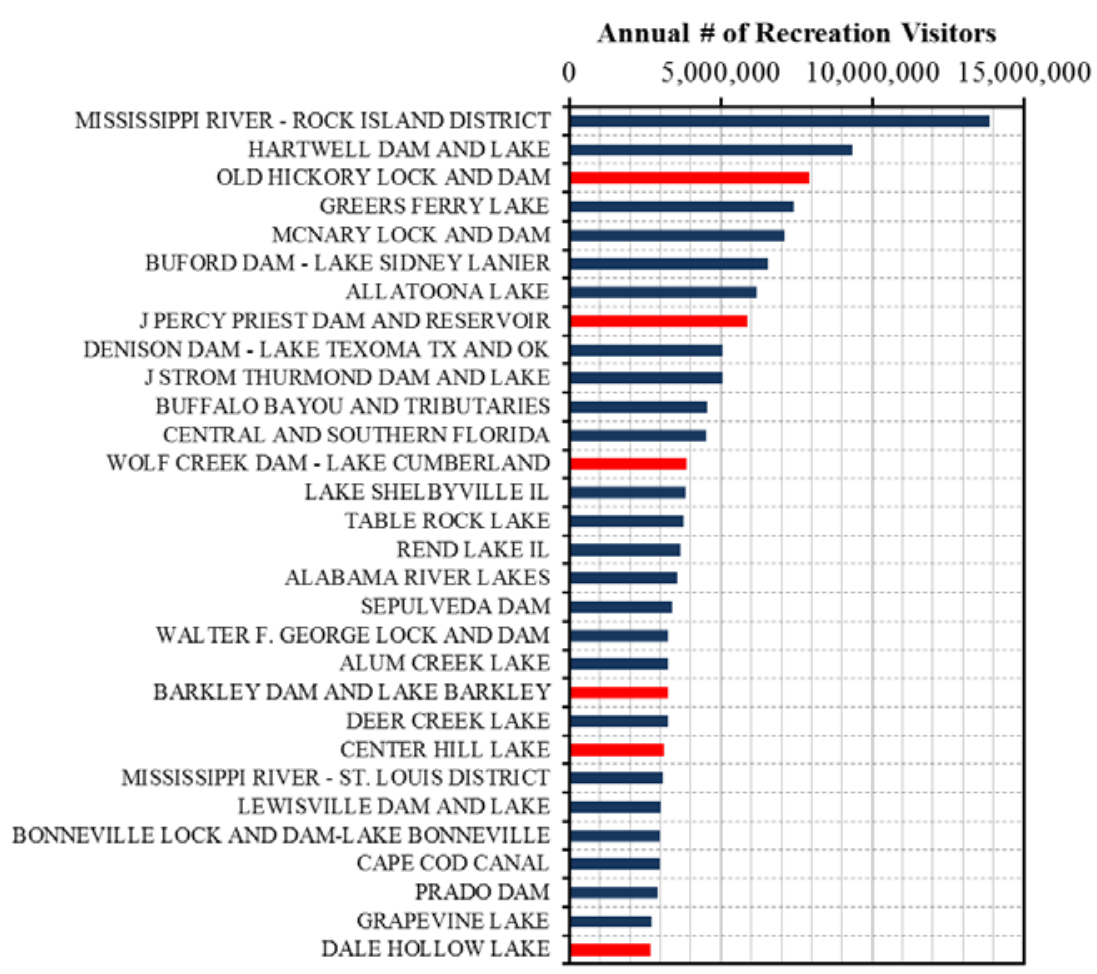

Figure 11 - Top USACE recreation projects by annual visitor. Cumberland system reservoirs are shown in red.

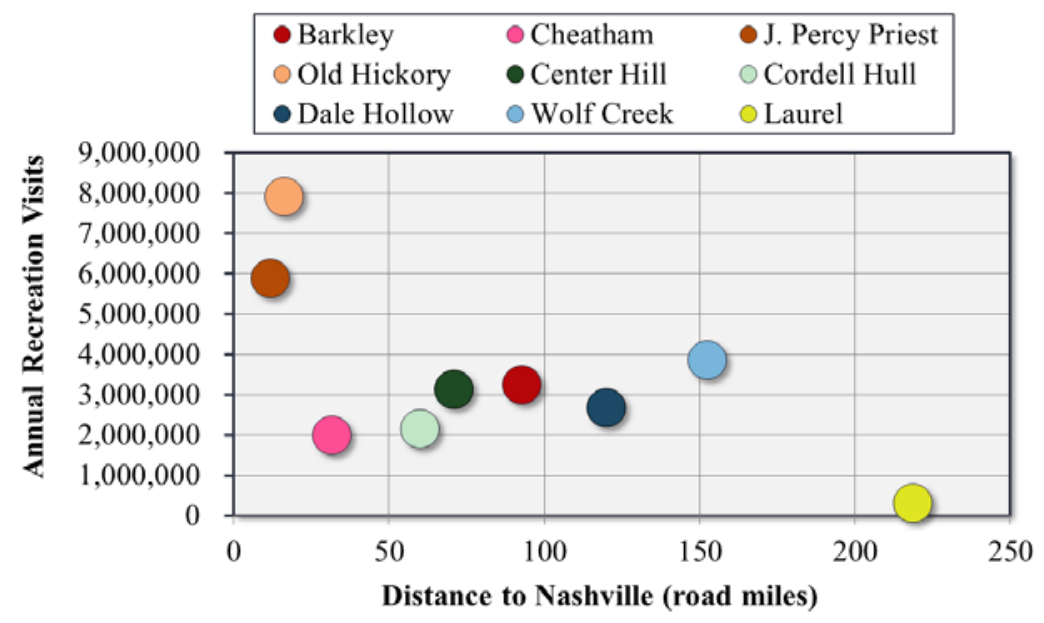

Figure 12 - Spatial distribution of reservoirs in relation to Nashville compared with annual recreation visitors.

The spatial and geometric characteristics of each reservoir show some interesting relationships with the recreation benefit. For smaller hydroelectric facilities with installed capacity less than $100 \mathrm{MW}$, there appears to be a trend of decreasing recreation benefit as a total percentage of overall multipurpose benefits as reservoir surface area becomes more expansive (Figure 13). The largest and third largest hydroelectric facilities in terms of installed capacity, Wolf Creek and Barkley, respectively, maintain the largest reservoir in terms of surface area, yet recreation benefits are the smallest percentage of total reservoir benefits compared to all other projects. 


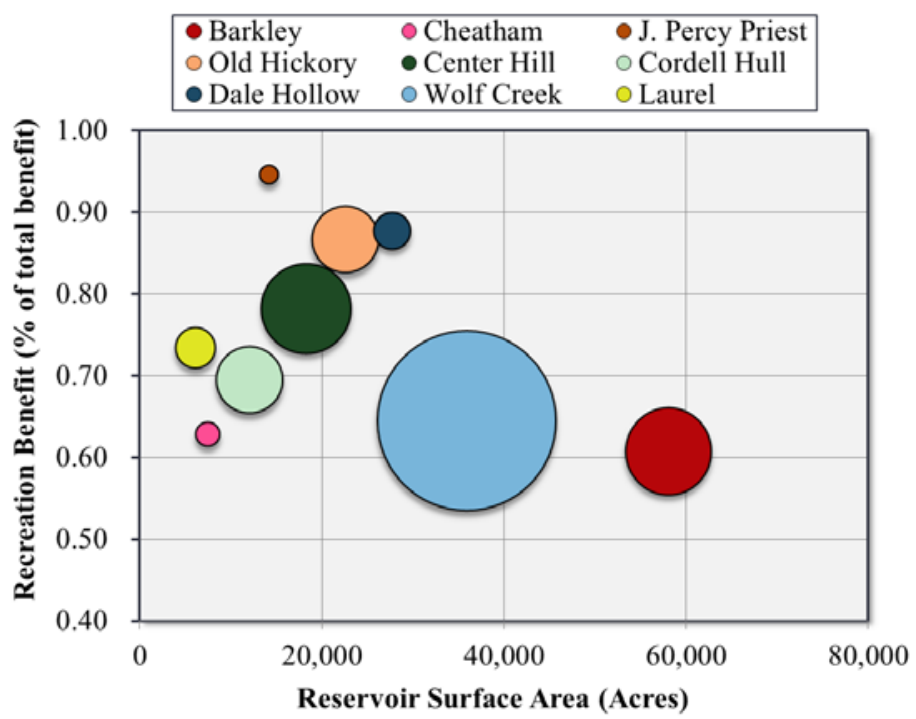

Figure 13 - Relationship between reservoir surface area and recreation benefit as a percentage of total benefit. Marker areas are scaled according to installed capacity.

The navigation benefit is only relevant for reservoirs on the main stem of the Cumberland that operate a lock: Barkley, Cheatham, Old Hickory, and Cordell Hull. The benefit is manifested as savings to shippers, which is dependent on the tonnage of commodities transported by barge. Barkley and Cheatham are the most active locks, located near the Ohio River and Nashville, respectively, and they record the largest navigation benefit (Figure 14). It appears that a large portion of tonnage shipped on the Cumberland is unloaded at or near Nashville, as the navigation benefit at Old Hickory is $50 \%$ that of Cheatham, though they are separated by approximately 65 river miles (compared to the 118 river mile difference between Barkley and Cheatham). The total number of locked vessels, both commercial and recreational, is highest at Old Hickory though the navigation benefit is the least of all active locks. The locks at Barkley and Cheatham are both $880 \mathrm{ft}$ long by $110 \mathrm{ft}$ wide, while Old Hickory Lock is $397 \mathrm{ft}$ long and $84 \mathrm{ft}$ wide, meaning Old Hickory must lock about twice as many vessels to attain the same navigation benefit. The high number of recreation vessels locked at Old Hickory is consistent with the recreation benefit, which is higher as a percentage of all benefits at Old Hickory than any of the other three reservoirs with locks.
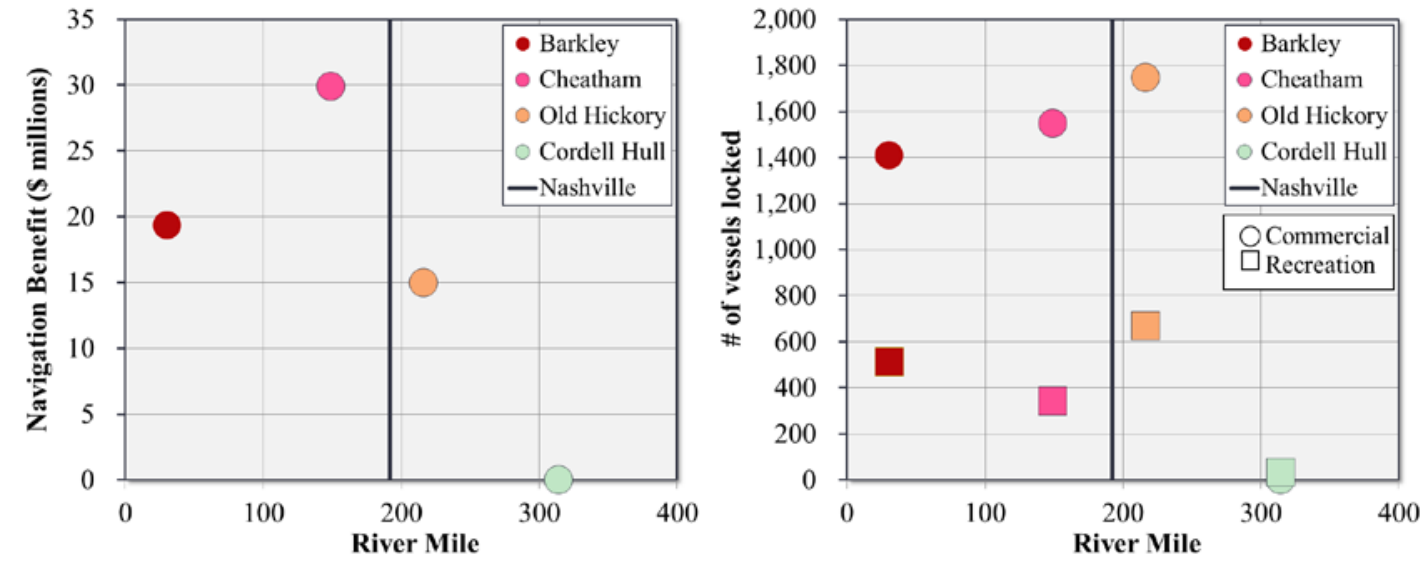

Figure 14 - Spatial distribution of navigation benefits in relation to Nashville (left). Count of vessels locked (right). 
The mix of commodity tonnage locked at each structure sheds light on the movement of goods throughout the region. The majority of tonnage shipped is coal, lignite, and coke products, followed by crude materials6 (Figure 15). The tonnage of coal, lignite, and coal coke increases traveling upstream, likely due to the demand at the Cumberland and Gallatin Fossil plants, each of which is upstream of the Old Hickory Lock. A significant drop in the tonnage of crude materials is observed between Chatham and Old Hickory, which likely reflects the delivery of goods to the Nashville metropolitan. Primary manufactured goods and petroleum products also see a decline after Cheatham, while food and farm products see a large decline between Barkley and Cheatham.

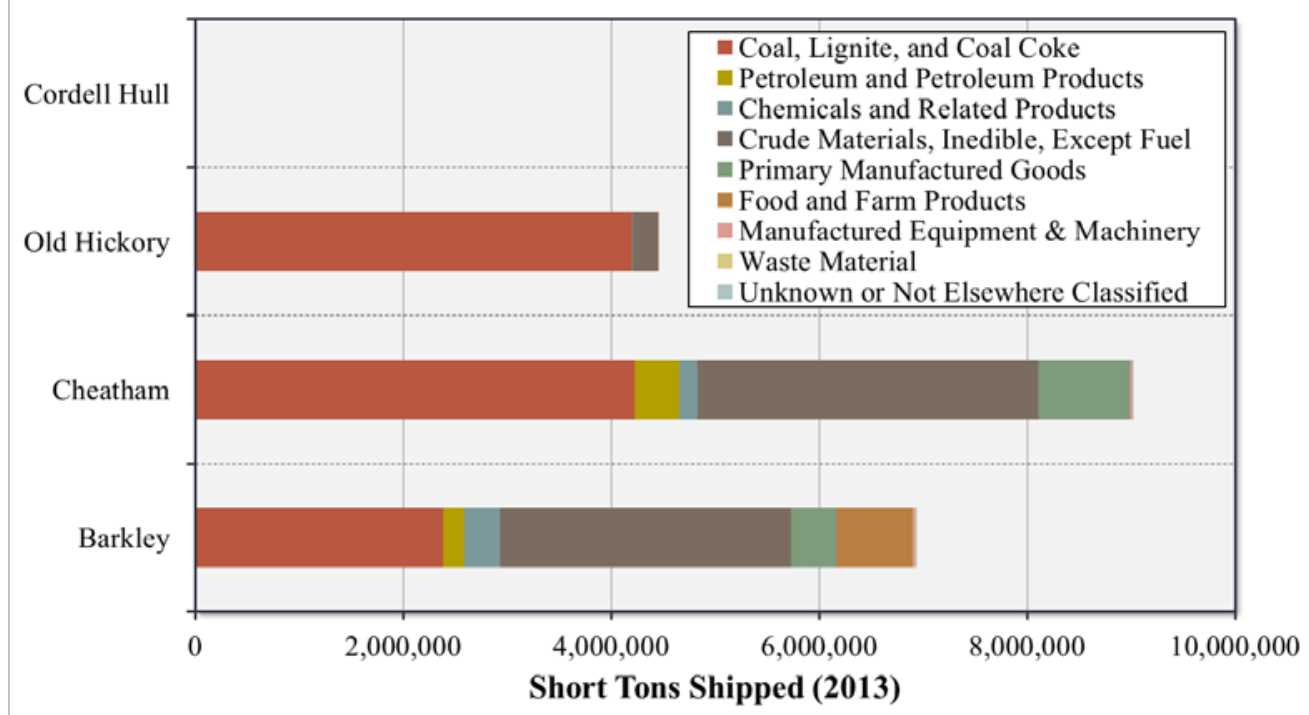

Figure 15 - Tonnage of commodity locked. Cordell Hull recorded 9600 tons of manufactured equipment and machinery locked, though the number is too small to display. The chart reflects reported tonnage and not reduced tonnage.

The distribution of flood damages avoided is shown in Figure 16. Generally speaking, the first priority in flood events is to discharge from reservoirs that have the lowest volume of flood storage remaining (USACE, 2015b). It follows logically that those reservoirs with the greatest storage capacity would provide the greatest benefit to the system, as is seen with Wolf Creek and Barkley. The tributary reservoirs of Center Hill, Dale Hollow, and J. Percy Priest provide about 27\% of the flood reduction benefit. In the reality of spatially inhomogeneous rainfall events, storage capacity at two distant locations does not provide the equivalent system benefit. If a compact, high powered storm hit Nashville, the storage capacity of Wolf Creek, 369 river miles upstream of Nashville, is useless. If safety is a prime concern, a reservoir may discharge regardless of the situation downstream. The total damage avoided by flood control structures is largely dependent on the stage-damage relationship of a major city, such as Nashville. It is possible that reservoirs closer to Nashville may provide a greater economic benefit, though a greater range of data and detail than are currently available would be needed to complete the analysis.

6 Crude materials include crude rubber, cork and wood, pulp and waste paper, textile fibers, or crude fertilizers. 


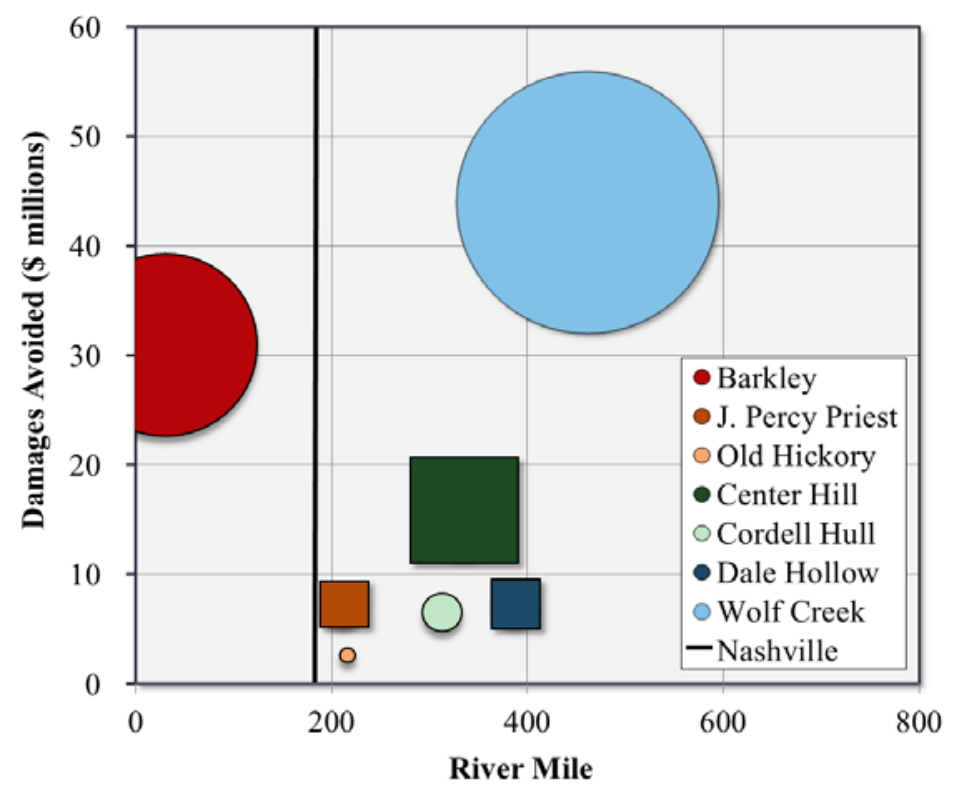

Figure 16 - Annual flood control benefit. Marker areas are scaled according to percentage of system storage capacity in the reservoir. Square markers indicate tributary reservoirs.

The hydropower benefit of each reservoir shows some system wide trends. In general, hydropower plants with greater installed capacity have a greater hydropower economic benefit as a percentage of total benefits (Figure 17). Cordell Hull, a run-of river plant with minimal flood storage capacity, shows the largest hydropower benefit percentage at $24 \%$. The smallest hydropower plant in terms of installed capacity, J. Percy Priest, also exhibits the smallest hydropower benefit percentage. The large economic benefit of recreation and the contribution of navigation near the Nashville city limit have some effect on the hydropower benefit. Moving away from the city in either direction, the hydropower benefit percentage tends to increase.

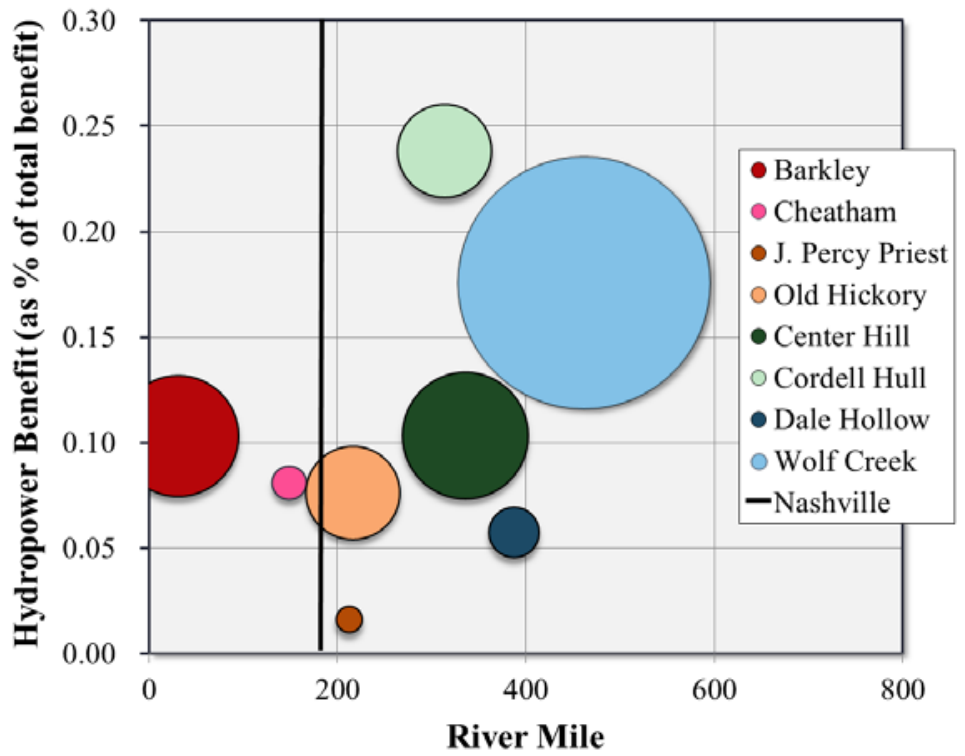

Figure 17 - Annual hydropower economic benefit. Marker areas are scaled according to installed capacity. 


\section{CONCLUSIONS AND FUTURE DIRECTIONS}

Federal hydropower dams in the U.S. support the grid with over 276,000 GWh of annual clean, renewable electricity. Over $80 \%$ of these dams are multipurpose projects, congressionally authorized for additional purposes including flood control, irrigation, navigation, water supply, and recreation. Each of these purposes has a significant and oftentimes quantifiable economic benefit. The magnitude of the benefit, measured here as an NED contribution, depends on the reservoir volume, geography, allocated storage, and installed capacity, among many other factors.

The benefits analysis revealed that, while a critical component of many multipurpose projects, power generation does not contribute the largest NED benefit in most cases. Rather, recreation and irrigation provided the largest economic benefit for federal multipurpose reservoirs. The contributing factors towards these benefit distributions include recreation visitors and spending, and the value of irrigated crops. For TVA and USACE reservoirs, recreation opportunities on surface waters and surrounding land attract millions of visitors annually. Most USBR reservoirs are located in the western U.S., where they are the primary supplier of water for irrigated crops, farmland, and livestock. These purposes contribute significant economic benefits to the multipurpose nature of hydropower reservoirs.

As hydropower installed capacity at a reservoir is increased, the benefit of hydropower is significant when only one or two additional purposes are present. For true multipurpose projects with four to five quantifiable uses, hydropower benefits represent a disproportionately smaller percentage of the total economic benefit. Large projects often benefit many stakeholders, and the most valuable multipurpose use is a function of many competing inputs, including location, mode of operation, and authorized use.

Future work can improve upon these efforts by developing a comparative methodology that accounts for the complexity of the interactions and effects associated with competing, complimentary, and interdependent multipurpose uses. A hierarchical assessment analyzing integral use comparison in a system as a whole from upstream to downstream may reveal some dependent relationships between water quantity and benefits distributions. The current work indicates future efforts will face significant headway in obtaining data, identifying all quantifiable benefits of a reservoir, and accounting for all interdependent effects in all circumstances under various hydrologic cycles.

This research is part of an ongoing effort to quantify the economic benefits of multipurpose hydropower reservoirs in the U.S. This analysis is representative of the best available data, which at times are challenging to gather as federal agencies, as well as offices within these agencies, do not have a systematic method for collecting and reporting dam and reservoir data. The present methodology was developed to standardize and quantify, as best as possible, a base case of the primary economic benefits of federal reservoirs. The ultimate objective of this research is to engage publicly-owned utilities and private sector hydropower dam owners so a complete national estimate of multipurpose benefits can be obtained. 


\section{REFERENCES}

Black, R., McKenney, B., Unsworth, R., \& Flores, N. (1998). Economic Analysis for Hydropower Project Licensing: Guidance and Alternative Methods. Retrieved from U.S. Fish \& Wildlife Service: http://www.fws.gov/policy/hydroindex.htm

Cameron, T., Shaw, D., Ragland, S., Callaway, J., \& Keefe, S. (1996). Using Actual and Contingent Behavior Data With Differing Levels of Time Aggregation to Model Recreation Demand. Journal of Agricultural and Resource Economics, 21(1), 130-149.

Cardno Entrix (2011). Economic Benefits of the Tennessee Valley Authority's Natural Resource Plan. Technical Report prepared for the Tennessee Valley Authority.

Carlson, B., Probst, D., Stynes, D., \& Jackson, R. (1995). Economic Impact of Recreation on the Upper Mississippi River System. Technical Report EL-95-16, U.S. Army Corps of Engineers.

Chang, L.-F., Lin, C.-H., \& Su, M.-D. (2008). Application of Geographic Weighted Regression to Establish Flood-Damage Functions Reflecting Spatial Variation. Water SA, 34(2), 209-215.

Chang, W. H., Stynes, D. J., Jackson, R. S., \& Propst, D. B. (2012). US Army Corps of Engineers Recreation Economic Assessment System. Computer Model and Online Database. Alexandria, VA: Institute for Water Resources, U.S. Army Corps of Engineers.

Comiskey, J. (2005). Overview of Flood Damages Prevented by U.S. Army Corps of Engineers Flood Control Reduction Programs and Activities. Journal of Contemporary Water Research and Education, 130, 13-19.

CUWA. (1994). The Value of Water Supply Reliability: Results of a Contingent Valuation Survey of Residential Customers. California Urban Water Agencies, Sacramento, CA.

Davis, R. M., \& al, e. (1996). Economic and Financial Analysis: Federal Energy Regulatory Commission Projects No. 1417 and No. 1835. U.S. Bureau of Reclamation, Economics Group.

Davis, S. (1985). Business Depth-Damage Analysis Procedures. Technical Report 85-R-5, U.S. Army Corps of Engineers.

Davis, S., \& Skaggs, L. (1992). Catalog of Residential Depth-Damage Functions Used by the Army Corps of Engineers in Flood Damage Estimation. Institute of Water Research, U.S. Army Corps of Engineers.

DOI. (2014). U.S. Department of the Interior Economic Report FY 2013 Draft.

dos Santos, M., Rosa, L., Sikar, B., Sikar, E., \& dos Santos, E. (2006). Gross greenhouse gas fluxes from hydro-power reservoir compared to thermo-power plants. Energy Policy, 34, 481-488.

Dwyer, J., Kelly, J., \& Bowes, M. (1977). Improved Procedures for Valuation of the Contribution of Recreation to National Economic Development. WRC Research Report No. 128, U.S. Department of the Interior.

EIA. (2013). Electric Power Annual 2012. Retrieved from http://www.eia.gov/electricity/annual/pdf/epa.pdf

FWS. (2011). National Survey of Fishing, Hunting, and Wildlife-Associated Recreation. U.S. Fish and Wildlife Service.

Gibbons, D. C. (1986). The Economic Value of Water. Resources for the Future, Inc.

IWR. (2010). Methdology Manual: Regional ECONomic System for Federal Spending. (U.S. Army Corps of Engineers) Retrieved from http://www.iwr.usace.army.mil/Portals/70/docs/missions/RECONS_\%20MethodologyManual1.pdf 
IWR. (2013). Value to the Nation of the U.S. Army Corps of Engineers Civil Works Program. Retrieved from http://www.iwr.usace.army.mil/Portals/70/docs/iwrreports/2013-R-09_vtn.pdf

Kasul, R., Stynes , D., Lee, L., Chang, W.-H., Jackson, R., Wibowo, C., et al. (2010). Characterization of Park Visitors, Visitation Levels, and Associated Economic Impacts of Recreation at Bull Shoals, Norfolk, and Table Rock Lakes. Technical Report ERDC/EL TR-10-18, U.S. Army Corps of Engineers.

Lekuthai, A., \& Vongvisessomjai, S. (2001). Intangible Flood Damage Quantification. Water Resources Management, 15(5), 343-362.

Madariaga, B., \& McConnell, K. (1984). Value of Irrigation Water in the Middle Atlantic States: An Econometric Approach. Southern Journal of Agricultural Economics, December.

Maupin, M. A., Kenny, J. F., Hutson, S. S., Lovelace, K. J., Barber, N. L., \& Linsey, K. S. (2014). Estimated Use of Water in the United States in 2010. U.S. Geological Survey.

Maupin, M., Kenny, J., Hutson, S., Lovelace, J., Barber, N., \& Linsey, K. (2014). Estimated Use of Water in the United States in 2010: U.S. Geological Survey Circular 1405.

Metropolitan Council. (2012). Assessment of economic impact of potentially discontinuing the operation of the Upper St. Anthony Falls Lock. Retrieved from http://metrocouncil.org/METC/files/a7/a74e4dbe-8548-451d-b357-2ac8af7b4dfd.pdf

NETL. (2009). Impact of Drought on U.S. Steam Electric Power Plant Cooling Water Intakes and Related Water Resource Management Issues. Retrieved from http://www.circleofblue.org/waternews/wpcontent/uploads/2010/08/Impact-of-Drought-on-Steam-Electric-Power-Plant-Cooling-WaterIntakes.pdf

Olsen, D. (2003). Economic Analysis Methodology Illustration and Review: Estimating the Value of Water for Key Resource Sectors from the Mainstem Columbia River. Technical Memorandum, Pacific Northwest Project.

Piper, S. (2009). Evaluating Economic and Financial Feasibility of Municipal and Industrial Water Projects. U.S. Bureau of Reclamation.

Pizzimenti, J., Olsen, D., \& Wilson, A. (2010). Quantifying the Non-Energy Benefits of Hydropower. Ceati Report No T082700-0363, GEI Consultants, Inc.

Propst, D., Stynes, D., Hee Lee, J., \& Jackson, R. (1992). Development of Spending Profiles for Recreation Visitors to Corps of Engineers Projects. Technical Report R-92-4, U.S. Army Corps of Engineers.

Russell, C. S. (1970). Industrial Water Use. National Water Commission.

SAFCA. (2011). Final Engineer's Report. Prepared by Parsons Brinckerhoff, Natomas Basin Local Assessment District.

Shabman, L., \& Stephenson, K. (2007). Environmental Valuation and Decision Making for Water Project Investment and Operations: Lessons from the FERC Experience. 2007-VSP-01, Institute for Water Resources.

Sims, R., Rogner, H.-H., \& Gregory, K. (2003). Carbon emission and mitigation cost comparisons between fossil fuel, nuclear and renewable energy resources for electricity generation. Energy Policy, 31, 1315-1326.

Smith, D. (1994). Flood Dmage Estimation - A Review of Urban Stage-Damage Curves and Loss Functions. Water SA, 20(3), 231-238.

Stynes, D., \& Propst, D. (1996). Micro-Implan Recreation Economic Impact Estimation System. User's Manual. 
Stynes, D. (2005). Economic Singificance of Recreational Uses of National Parks and Other Public Lands. Social Science Research Reveiew, 5(1), 1-36.

TVA (2012). Water Use in the Tennessee Valley for 2010 and Projected Use in 2035.

University of Kentucky and University of Tennessee. (2014). Inland navigation in the United States: An evaluation of economic impacts and the potential effects of infrastructure investment. Retrieved from http://www.nationalwaterwaysfoundation.org/documents/INLANDNAVIGATIONINTHEUSDE CEMBER2014.pdf

USACE. (2000). Planning Guidance Notebook. ER 1105-2-100.

USACE. (2014). Economic Guidance Memorandum 15-01.

USBR. (2011). Draft: Economic Valuation Appendix. Retrieved from https://www.usbr.gov/mp/slwri/docs/Appendices/MP700_SLWRI_039_AppxEcon.pdf

Ward, F., Roach, B., \& Henderson, J. (1996). The Economic Value of Water in Recreation: Evidence from the California Drought. Water Resources Research, 32(4), 1075-1081.

White, E., Goodding, D., Stynes, D. (2013). Estimation of national forest visitor spending averages from National Visitor Use Monitoring: round 2. General Technical Report - Pacific Northwest Research Station, USDA Forest Service 2013 No. PNW-GTR-883. 